\title{
FEATURE INHERITANCE, VP PHASES AND THE INFORMATION STRUCTURE OF SMALL CLAUSES*
}

\author{
Ángel L. Jiménez-Fernández \& Vassilios Spyropoulos
}

Abstract. In this paper we explore the interaction of discourse properties in the syntax of small clauses from a cross-linguistic perspective. In line with Chomsky's (2007, 2008) idea that phasal properties should be extended to all phases, we argue for a strict parallelism between C-T and $v-\mathrm{V}$, suggesting that $v$ enters the derivation with both agreement and discourse features. These features may be inherited by $\mathrm{V}$ depending on the relevant language. Building on Miyagawa (2010) and Jiménez-Fernández (2010), we claim that in Spanish and Greek, in contrast with English, both agreement and discourse features are inherited by V. This strategy accounts for the different order rearrangements detected in small clauses. The proposal can easily be extended to other languages such as Italian, Serbo-Croatian, Russian and Ukrainian, as opposed to French, Norwegian, Afrikaans and German.

\section{Introduction}

The goal of this work is to explore the interaction of discourse properties in the syntax of small clauses (SCs, hereafter) from a cross-linguistic perspective. In line with Chomsky's $(2007,2008)$ idea that phasal properties should be extended to all phases, we will argue for a strict parallelism between $\mathrm{C}-\mathrm{T}$ and $v-\mathrm{V}$, claiming that $v$ enters the derivation with both agreement and discourse features, $\varphi$-features and $\delta$-features, respectively. Miyagawa $(2005,2010)$ and Jiménez-Fernández (2010) have claimed that languages may be classified according to the type of feature that they highlight in the CP-domain: either $\varphi$-features or $\delta$-features or both. We assume that giving prominence to one type of feature is crucially related to the possibility of the feature-inheritance mechanism that defines phasal heads. Concerning the CP-system, this leaves us with a threefold typology of languages: those that allow lowering of only $\varphi$-features, those permitting only the percolation of $\delta$-features, and those

\footnotetext{
*An earlier version of this paper was presented at the 2010 LAGB meeting in Leeds. We are very thankful to the audience for their comments. In addition, we are grateful to Shigeru Miyagawa, João Costa, Pilar Barbosa, Theresa Biberauer, Merete Anderssen, Christoph Ehlers, Violeta Demonte, Alain Rouveret and Christer Platzack, among others, for their comments and/or data. No doubt they have contributed in making a stronger paper. We are also thankful to Cristine Schaetz for revising the English. All possible errors are ours. The following abbreviations are used in the glosses: ACC $=$ accusative, GEN $=$ genitive, $\mathrm{CL}=$ clitic, $\mathrm{FEM}=$ feminine, $\mathrm{FOC}=$ focus, $\mathrm{FUT}=$ future, $\mathrm{IND}=$ indicative, $\mathrm{MSC}=$ masculine, NEUT $=$ neuter, $\mathrm{NOM}=$ nominative, $\mathrm{PRES}=$ present, $\mathrm{PL}=$ plural, $\mathrm{SG}=$ singular , $\mathrm{SUB}=$ subjunctive, $\mathrm{TOP}=$ topic.
} 


\section{2 Ángel L. Jiménez-Fernández \& Vassilios Spyropoulos}

that show no preference and require the transmission of both $\varphi$ - and $\delta$ features (Jiménez-Fernández 2010, 2011).

(1) Feature Inheritance ( $\varphi$ : agreement features, $\delta$ : discourse features) (adopted from Jiménez-Fernández 2010)

a. $\mathrm{C}_{\varphi, \delta} \rightarrow \mathrm{T}_{\delta} \ldots \quad$ (discourse-prominent, e.g. Japanese, Korean)

b. $\mathrm{C}_{\varphi, \delta} \rightarrow \mathrm{T}_{\varphi} \ldots \quad$ (agreement-prominent, e.g. English)

c. $\mathrm{C}_{\varphi, \delta} \rightarrow \mathrm{T}_{\varphi, \delta} \ldots$ (discourse-prominent, agreement-oriented, e.g. Spanish, Turkish, Greek) ${ }^{1}$

As regards phasal $v$, languages choose the type of feature to be highlighted and lowered onto $\mathrm{V}$ and a parallel behaviour is detected in the $v$-V system. Our discussion of phasal $v$ will focus on argument small clauses. In this connection, English will only emphasise $\varphi$-features, hence requiring a fixed word-order in SCs (see (2) below). Nevertheless, languages such as Spanish and Greek give prominence to both agreement and discourse features by passing them over onto V. This typology can be sketched as follows (partially adapted from Jiménez-Fernández forthcoming):

(2) Feature Inheritance in $v$-V system:

a. $v_{\varphi, \delta} \rightarrow \mathrm{V}_{\varphi} \ldots \quad$ (agreement-prominent, e.g. English)

b. $v_{\varphi, \AA} \rightarrow \mathrm{V}_{\varphi, \delta} \ldots$ (discourse-prominent, agreement-oriented, e.g. Spanish, Greek)

\footnotetext{
${ }^{1}$ As an anonymous reviewer has pointed out, there is one type in this classification which is missing, namely the possibility that all grammatical features (both agreement and discourse) are retained in C. To our knowledge, this is a natural gap in language since there is not a single language where neither the $\varphi$-features nor the $\delta$-features are inherited by T (Shigeru Miyagawa, p.c.). As stated in the main text, this is a threefold typology. We can speculate that the non existence of this option is related to the EPP and Phase Impenetrability Condition (PIC), in the sense that without feature inheritance there would be no EPP-forced movement in T and hence any movement would be blocked by the PIC. See Chomsky $(2007,2008)$ and Richards (2007) on feature inheritance and phasehood. In any case, we remain agnostic with respect to the empirical existence of this forth option and its theoretical justification.
} 
The double nature of the VP-area will justify the rearrangements identified in $\mathrm{SCs}^{2}$, which result from a strict information structure pattern [Top - Foc], as evident from the Spanish and Greek examples in $(4-7):^{3}$

\title{
(3) English:
}

a. Q: Who do you consider so clever?

A: I consider Susan very clever.

b. Q: How do you consider Susan?

A: I consider Susan very clever.

(4) Spanish:
Q: ¿A quién consideras
muy lista?
to whom consider-PRES.2SG very clever-FEM.SG
'Whom do you consider very clever?'

\begin{abstract}
${ }^{2}$ Our work concentrates on the syntax and information structure of argument SCs. However, the same word order alternations hold for non-subcategorized SCs or secondary predicates in languages such as Spanish and Greek. When the secondary predicate modifies the matrix object, either [DP XP] or [XP DP] orders are licit (Demonte 1988, Demonte \& Masullo 1999):
\end{abstract}

(i) Spanish
a. Juan comió la carne cruda.
Juan eat -PAST.3SG the meat raw
b. Juan comió cruda la carne.
Juan eat-PAST.3SG raw the meat
'Juan ate the meat raw.'

(ii) Greek
a. o janis efare to kreas omo
the John-NOM eat-PAST.3SG the meat ${ }_{\mathrm{NEUT}}$-ACC meat $_{\mathrm{NEUT}}$-ACC
b. o janis efare omo to kreas
the John-NOM eat-PAST.3SG raw-NEUT.SG.ACC the meat NEUT-ACC $^{-}$

Interestingly, the use of one order or the other is crucially dependent on the information structure of the relevant sentence. For instance, if the focus is on the object, the latter is placed after the secondary predicate ([XP DP] order). On the other hand, if the predicate is the focus, it occupies the final position ([DP XP] order). In languages such as English, this is simply not possible because the object cannot be separated from the verb:

(iii) English
a. John ate the meat raw.
b.*John ate raw the meat.

For more information on secondary predicates, see Guémann (1990), Mallén (1991), Demonte \& Masullo (1999), among many others.

${ }^{3}$ In the paper, italics are used for topics and underlining for information focus (capitals indicate contrastive focus). The symbol \# must be understood as non felicitous in the relevant context with the intended discourse reading. Likewise, the symbol * means that the example is strongly unnatural. In addition, the Greek (though not the Spanish) examples are provided with case marked glosses, since morphological case is overt in this language. 
4 Ángel L. Jiménez-Fernández \& Vassilios Spyropoulos
A': Considero muy lista $\quad$ Susana. $^{4}$ consider-PRES.1SG very clever-FEM.SG to Susana '*I consider very clever Susana.'
A": \#Considero a Susana muy lista. consider-PRES.1SG to Susana very clever-FEM.SG 'I consider Susana very clever.'

(5) Spanish:
Q: ¿Cómo consideras
a Susana?
how consider-PRES.2SG to Susana
'How do you consider Susana?' consider-PRES.1SG very clever-FEM.SG to Susana
'*I consider very clever Susana.'
A": Encuentro a Susana muy lista. consider-PRES.1SG to Susana very clever-FEM.SG 'I consider Susana very clever.'
A': \#Considero muy lista a Susana.

(6) Greek:
Q: pjon
Aeoris
poli eksipno?
who-MSC.ACC consider-2SG very clever-MSC.SG.ACC
'Whom do you consider very clever?'
A': $\theta$ eoro
poli eksipno
to jani
consider-1SG very clever-MSC.SG.ACC the John-ACC
A": \#Aeoro to jani poli eksipno.
consider-1SG the John-ACC very clever-MSC.SG.ACC
'I consider John clever.'

(7) Greek:

Q: ti $\quad$ teoris to jani?

what-NEUT.ACC consider-2SG the John-ACC

'How do you consider John?'
A': \#祭oro poli eksipno to jani consider-1SG very clever-MSC.SG.ACC the John-ACC
A": Өeoro to jani poli eksipno. consider-1SG the John-ACC very clever-MSC.SG.ACC 'I consider John clever.'

Both (6A") and (7A') in Greek, as well as their Spanish counterparts (4A" and $\left.5 \mathrm{~A}^{\prime}\right)$ are non felicitous in the contexts described above. However, the

\footnotetext{
${ }^{4}$ Traditionally, a topic corresponds to an argument of a sentence, never to a predicate (Reinhart 1981; though see Raposo \& Uriagereka 1995 for a different view). When we say that the SC subject is the focus and its predicate is the topic, we really mean that this predicate is part of the background information. This background topic moves to allow the subject to occupy the focus position. In this respect, the kind of movement involved can be seen as Zubizarreta's (1998) prosodically-motivated movement. We will come back to this p-movement below.
} 
word order they exemplify may become felicitous if the appropriate constituent is identified as focus or topic. Concentrating on Spanish, if (4A") has an intonation by which the DP Susana receives focus (see the discussion below), the sentence is correct in all aspects, but the AP muy lista is felt to be right dislocated and separated by a pause from the rest of the sentence, or at least de-stressed. ${ }^{5}$ As regards Greek, similar discourse-related restrictions hold. The [XP DP] pattern is preferred over the [DP XP] one when asked about the SC subject (6), whereas the contrary holds when asked about the SC predicate (7). (6A') and (7A') are felicitous answers to (6Q) and (7Q) respectively only if the relevant items (the DP and the XP respectively) are emphatically stressed. ${ }^{6}$

\footnotetext{
${ }^{5}$ In Greek, the construction [DP XP] can answer a question about the DP only if the DP dislocated element.

(i) Q: ti

Aeoris to jani?

what-NEUT.ACC consider-2SG the John-ACC

'How do you consider John?'
A': Өeoro
EKSIPNO
to jani
consider-1SG clever-MSC.SG.ACC the John-ACC
A": ton $\quad$ eeoro EKSIPNO to jani
CL3-MSC.SG.ACC consider-1SG clever-MSC.SG.ACC the John-ACC

'I consider John clever.'
} is emphatically stressed. In such examples the XP is not separated by pause from the DP, but rather it has the lowering intonation appropriate to the de-accentuation of post-foci material (Revithiadou 2005). Thus, it is not safe to conclude whether it is a right-dislocated element as it may be in Spanish. Similarly, in the construction [XP DP] with emphasis on XP answering a question about the XP, the XP is not separated by pause from the DP. In fact, it can be separated by a pause only if the DP is clitic doubled, in which case it is clearly a

${ }^{6}$ (7Q) has also another felicitous answer (in fact the most preferred one), which involves a clitic-doubling/dislocation construction:
(i) (to jani) i maria ton
the John-ACC the Mary-NOM CL3-MSC.SG.ACC
eksipno (to jani)

clever-MSC.SG.ACC the John-ACC

'Mary considers John clever.'

In Spanish, we can also find the clitic construction and the subject may occur in either of the two positions:
(ii) (A Juan) María lo
considera $\left(?^{*}\right.$
a Juan) listo
(a Juan).
to John Mary CL3-MSC.SG.ACC consider-PRES.3SG to John clever-MSC.SG to John
'Mary considers John clever.'

Leaving the SC subject in its original place yields an ungrammatical outcome, even in those varieties, such as Rioplatense Spanish, which are more prolific in the use of clitic doubling (Violeta Demonte, p.c.). It should be made clear, though, that clitic doubling/dislocation falls outside the scope of this paper, basically because, despite its connection with the structures under study, in order to do justice to the role of clitic doubling in information structure, separate work on this specific topic would be needed. We are mainly interested in the rearrangements of the relevant parts of the SCs (i.e. displacement) without the extra mechanism of clitic doubling/dislocation. For a discussion of the role of clitic left dislocation in information structure see López (2009) for Spanish and Anagnostopoulou $(1999,2005)$ and Androulakis $(2001,2010)$ for Greek. 


\section{6 Ángel L. Jiménez-Fernández \& Vassilios Spyropoulos}

We propose that these word order differences can be accounted for in a principled way if the behaviour of phasal $v$ in a specific language is parallel to that of C. English will be predicted not to allow for rearrangement in SCs, while Spanish and Greek are expected to permit the opposite option. ${ }^{7}$ The permutations identified in such languages are crucially contingent upon the discourse properties of SCs. Binding effects, the distribution of floating quantifier and specificity effects provide us with some arguments in favour of our analysis of SCs, based on the kind of features highlighted in the relevant language. Different interpretations of anaphors will reveal that although the SC subject is generated inside the $\mathrm{SC}$, it moves to a specific position within the matrix VP.

On our analysis of word order, there is a parallelism between the information structure of argument SCs and that of matrix clauses. It is generally acknowledged (Zubizarreta 1998, Belletti 2004, López 2009 and Alexiadou 1999, Georgiafentis \& Sfakianaki 2004 among many others) that in pro-drop languages final post-verbal subjects occupy a focus position, which distinguishes them from pre-verbal subjects. Similarly, in SCs when the subject is placed in final position it is because it is the focus of the SC.

\section{Argument small clauses: Discourse properties}

In this section we examine the relevance of the discourse structure of SCs in the selection of a specific word order, which is based upon the choice of which SC constituent is the topic of the embedded construction. As is well-known, some languages are more flexible than others, allowing for

\footnotetext{
${ }^{7}$ One reviewer observes that the reverse order of argument SCs is also available sometimes in English:

(i) I consider clever all those young men and women who dedicate their time to the study of languages.
}

As this reviewer claims, the example typically occurs as an answer to a question such as 'Who do you consider clever?', which is an indication that in the answer the information satisfying the request in the question will be the focus. While in English information focus is characterised by phonological devices (especially, stress), when the focused constituent is long it tends to occupy final position. This is the case in (i), illustrating what is commonly referred to as End-Weight Principle (Leech \& Svartvik 2002). However, this type of reordering has been claimed to be post-syntactic ever since the seminal work by Ross (1967). In our terms, this means that there is no need for any syntactic computation to obtain examples such as (i), since the operation at issue is phonological.

An alternative syntax-based analysis of low subjects in English is provided by Culicover \& Levine (2001) and Culicover \& Winkler (2008), who claim that inversion in English is due to the fact that the subject remains in its original position. In other words, in (i) the DP subject of the SC stays in situ (maybe because it is too heavy to move). If SCs project some sort of functional category whose specifier is the target of the subject, examples such as (i) can be explained by assuming that the predicate moves to specifier of this functional projection to satisfy its EPP feature, as in locative inversion. In other words, inversion in (i) has nothing to do with movement to the VP-domain of the matrix clause. 
an alternation of [DP XP] and [XP DP], while others show a very rigid [DP XP] order. The rearrangements detected in SCs will just be a consequence of the discourse properties of their members.

\subsection{Preliminary assumptions}

One of the main problems in current research on information structure is that there is a tendency to deal with notions such as topic or focus without an explicit definition. In our work we assume the definition of topic and the classification of topics which Frascarelli \& Hinterhölzl (2007) put forth and which are further extended by Bianchi \& Frascarelli (2010).

Three types of topics can be identified according to Frascarelli \& Hinterhölzl (2007:87):

(8) a. aboutness topic: "what the sentence is about" (Reinhart 1981, La mbrecht 1994); in particular a constituent that is "newly introduc ed, newly changed or newly returned to" (Givón 1983: 8), a cons tituent which is proposed as "a matter of standing and current in terest or concern" (Strawson 1964).

b. contrastive topic: an element that induces alternatives which have no impact on the focus value and creates oppositional pairs with respect to other topics (Kuno 1976, Büring 1999).

c. familiar topic: a given or accessible (cf. Chafe 1987) constituent, which is typically de-stressed and realized in a pronominal form (Pesetsky 1987); when a familiar topic is textually given and D-li nked with a pre- established aboutness topic, it is defined as a co ntinuing topic (cf. Givón 1983).

Our attention will be primarily focused upon the third type. The familiar topic mingles interface notions such as D-linking and givenness and it is prosodically marked with a low tone. This is exactly the topic that we find in argument small clauses:

(9) $Q:$
¿Qué piensas de María?
what think-PRES.2SG of Mary
'What do you think about Mary?'
A: Encuentro a María muy atractiva. find-PRES.1SG to Mary very attractive
'I find Mary very attractive.'

In the answer the SC subject Mary corresponds to a familiar topic. The information provided by this constituent has been established before in the question. This implies that it is given and D-linked.

As regards the notion of focus, there is a well-grounded line of research (Rizzi 1997, É. Kiss 1998, Zubizarreta 1998, Belletti 2004, etc.) in which a 
distinction is made between information focus and contrastive focus. Information focus is purely new information which satisfies the request of a question, whereas contrastive focus is new information which conveys a contrast or correction with respect to previous assertion. We will concentrate mainly on information focus, though sometimes we also pay attention to contrastive focus.

Following common practice, the informational focus of a sentence may be identified by means of question/answer pairs. The new information in the answer corresponding to the $w h$-expression in the question will constitute the focus, while the rest of the construction will be part of the old (given) information expressed in the topic part (Aboh 2010). The traditional 'Top - Foc' partition explains the differences in terms of acceptability identified in (3-7).

The given nature of information is what describes topics, especially familiar topics. As stated above, this given information can occur in the sentence as topic or background information. We take the SC subject to be a topic when it conveys old information, corresponding to the argument that the content of the SC is about. However, the SC predicate may simply be background material. Yet we use the label 'Top' to cover both topics and background.

A further point about the status of the SC predicate is the classification of predicates in two groups, namely stage-level (SL) and individual-level (IL) predicates (Kratzer 1995, Diesing 1992). Stage-level predicates denote a temporary property of the subject, while individual-level predicates express a permanent property. This semantic distinction is crucially related to the information structure of SCs. According to Raposo \& Uriagereka (1995), individual-level predicates are predicated of a topic, whereas stage-level predicates are not (the latter is an all-focus construction, in the sense of Erteschik-Shir 1997). Jiménez-Fernández (2012) has shown that stage-level constructions can further be divided into two, all-focus sentences (where there is a null topic) and topic comment sentences. In the realm of SCs, this three-fold classification can be illustrated by examples in (10) and the corresponding information structures in (11):
a. Considero a Ángela muy traviesa. consider-PRES.1SG to Angela very naughty 'I consider Angela very naughy'
b. Veo a Ángela muy cansada. see-PRES.1SG to Angela very tired 'I see Angela very tired'

(11) a. Considero [Top a Ángela [Comment muy traviesa]]

b. Veo [Top TOP [Comment a Ángela muy cansada]]

c. Veo [Top a Ángela [Comment muy cansada]] 
Our approach to argument SCs is limited to those constructions where the predicate is either IL or SL and the subject may either be a topic (moving to Spec,VP) or a focus (staying in its original position).

\subsection{Topic and focus in argument SCs: describing cross-linguistic data}

Languages like English do not exhibit the SC alternation. For the questions in (3) there is only one possible answer (I consider Susan clever vs. * I consider clever Susan). This is accounted for by the English preference for topic and focus in situ in SCs, due to a purely phonological strategy.

Conversely, in languages like Spanish and Greek the order of constituents in SCs alternates between [DP XP] and [XP DP], but it seems that the reason to prefer one order or the other crucially depends on discourse factors. As regards Spanish, we assume Zubizarreta's (1998) and Ordóñez's (1998) claim that the element containing nuclear stress and, consequently, functioning as informational focus should appear last in the sentence. This explains why in (4) the preferred order is [XP DP], where the DP is the focus constituent and the predicate AP constitutes an embedded topic, while in (5) the reverse order is more felicitous to indicate that now the focus is the predicative AP and the topic is the embedded DP subject. ${ }^{8}$

Spanish and Greek also show a purely phonological recourse to mark the focus and the topic pieces of an utterance. Accordingly, if the nonfelicitous sentences above are assigned a proper intonation in an appropriate context, the degradation disappears. Thus, if we ask about the subject of the SC, the most felicitous answer follows the [XP DP] order and focus falls on the subject (see examples (4) and (6)). However, the pattern [DP XP] is also tolerated in such a context, but the subject has some kind of contrastive flavour, typical of contrastive focus. ${ }^{9}$ Contrastive focus can be assigned either in the left periphery of the whole sentence or in situ, as is illustrated by examples (12A.a) and (12A.b), respectively (capitals are used to indicate contrastive focus):

$$
\begin{aligned}
& \text { Q: ¿A quién consideras muy listo? } \\
& \text { to whom consider-PRES.2SG very clever } \\
& \text { 'Who do you consider very clever?' }
\end{aligned}
$$

\footnotetext{
${ }^{8}$ The word order alternation in SCs has been explored by Francom (2003). She proposes that in Spanish Stowell's (1991) restructuring rule applies in the narrow syntax, as opposed to English. She also identifies discourse properties in SCs which are responsible for the rearrangement of word order. However, Francom's discussion focuses on the difference between sentences such as Ella encontró confuso el informe 'She found confusing the report' (containing an SC) and Ella encontró el informe confuso 'She found the report confusing' (showing ambiguity between an SC reading and a DP object reading).

${ }^{9}$ For differences between the two types of focus, see É. Kiss (1998). For a proposal that dispenses with this distinction see Kenesei (2006), who claims that both contrastive and informational foci involve some sort of identification, which justifies the unitary approach to focus types.
} 
A: a. A JUAN considero muy listo (no a Pedro). to John consider-PRES.1SG very clever (not to Peter) 'John, I consider clever (not Peter).'
b. Considero A JUAN muy listo (no a Pedro). consider-PRES.1SG to John very clever (not to Peter) 'I consider John very clever (not Peter).'

In addition to the sequence [XP DP], the two sentences in (12Aa-b) can be clearly used as an answer to the question 'Who do you consider clever?'. Nevertheless, in these two instances there is a sense of contrast which is simply optional for the [XP DP] ordering in an appropriate context. From this it follows that the non-felicitous character of the pattern [DP XP] vanishes if the DP is assigned corrective/contrastive stress. This is further illustrated by the different interpretations in (13):

(13) Q: ¿A quién encuentras muy guapa?

to whom find-PRES.2SG very beautiful-FEM.SG

'Whom do you find very beautiful?'

A': Encuentro muy guapa a Jimena. find-PRES.1SG very beautiful-FEM.SG to Jimena 'I find Jimena very beautiful.'

A": \#Encuentro a Jimena muy guapa. find-PRES.1SG to Jimena very beautiful-FEM.SG 'I find Jimena very beautiful.'

A"': Encuentro A JIMENA muy guapa. find-PRES.1SG to Jimena very beautiful-FEM.SG 'It's Jimena that I find very beautiful.'

From the examples in (13) we can conclude that Spanish may allow for the pattern [DP XP] in the answer to a question about the SC subject, but only if the relevant DP subject is assigned contrastive focus in situ. Otherwise, the [XP DP] order is preferred. Similarly, Greek also instantiates the focus in-situ strategy, which again accounts for the correctness of the pattern [DP XP] with a focused DP in an answer to a question about the subject of an SC:

$$
\begin{aligned}
& \text { Q: pja vriskis poli omorfi? } \\
& \text { who-FEM.SG. ACC find-2SG very beautiful-FEM.SG.ACC } \\
& \text { 'Whom do you find very beautiful?' } \\
& \text { A': vrisko poli omorfi ti maria. } \\
& \text { find-1SG very beautiful-FEM.SG.ACC the Maria-ACC } \\
& \text { 'I find Maria very beautiful.' } \\
& \text { A": *vrisko ti maria poli omorfi. } \\
& \text { find-1SG the Maria-ACC very beautiful-FEM.SG.ACC } \\
& \text { 'I find Maria very beautiful.' }
\end{aligned}
$$




\section{A"': vrisko TI MARIA poli omorfi. find-1SG the Maria-ACC very beautiful-FEM.SG.ACC 'It is Maria that I find very beautiful.'}

The typology of verbs which subcategorise for argument SCs is quite varied. According to Demonte \& Masullo (1999:2471), based on Spanish, SCs can be selected by volitional/epistemic verbs (15a), causative verbs (15b), and supporting verbs (15c):
a. Juzgo tu propuesta muy original judge-PRES.1.SG your proposal very original 'I judge your proposal very original.'(D\&M's ex. 12ia)
b. Los inesperados abandonos volvieron a mi amiga the unexpected abandonments turn-PAST.3.SG to my friend desconfiada. distrustful
'The unexpected abandonments made my friend distrustful.' (partially modified D\&M's ex. 12ib)
c. Tiene la sonrisa suave. have-PRES.3SG the smile soft 'She/he has the smile sweet.'

(D\&M's ex.12ii)

Interestingly, the SC selected by all these types of verbs is open to an alternation in word order when the subject is focused and hence occurs in the pattern [XP DP]:
(16)
a. Juzgo muy original tu propuesta. judge-PRES.1.SG very original your proposal 'I judge your proposal very original.'
b. Los inesperados abandonos volvieron desconfiada the unexpected abandonments turn-PAST.3.SG distrustful a mi amiga. to my friend
'The unexpected abandonments made my friend distrustful.'
c. Tiene suave la sonrisa have-PRES.3SG soft the smile 'She/he has the smile sweet.'

The same pattern occurs in Greek:
a. vrika
tin protasi $\mathrm{su}$ poli
find-PAST.1SG the proposi-ACC CL2-SG.GEN very prototipi original-FEM.SG.ACC
'I found your proposal very original.' 
12 Ángel L. Jiménez-Fernández \& Vassilios Spyropoulos

b. i kaӨisterisis ekanan ti maria the delay-PL.NOM make-PAST.3PL the Mary-ACC ðispisti

distrustful-FEM.SG.ACC

'The delays made Mary distrustful.'

c. exi ton kipo tu panta peripiimeno

have-3SG the garden-ACC CL3-MSC.SG.GEN always trim-MSC.SG.ACC 'He has his garden always trim.'

(18) focus on subject $\rightarrow$ [XP DP]

a. vrika poli prototipi tin protasi

find-PAST.1SG very original-FEM.SG.ACC the proposi-ACC $\mathrm{su}$

CL2-SG.GEN

'I found your proposal very original.'

b. i kaӨisterisis ekanan dispisti ti

the delay-PL.NOM make-PAST.3PL distrustful-FEM.SG.ACC the maria

Mary-ACC

'The delays made Mary distrustful.'

c. exi panta peripiimeno ton kipo tu

have-3SG always trim-MSC.SG.ACC the garden-ACC CL3-MSC.SG.GEN 'He has his garden always trim.'

As shown in Jiménez-Fernández (forthcoming), the alternation in SCs is extended to other languages like Italian (19) or Serbo-Croatian (20):

(19) a. Gianni considera Maria intelligente.

Gianni consider-PRES.1.SG Maria intelligent

b. Gianni considera intelligente Maria.

'Gianni considers Mary intelligent.' (Belletti \& Shlonsky 1995)

(20) a. Smatram Mariyu nevinom.

consider-PRES.1.SG Mary-ACC innocent

b. Smatram nevinom Mariyu.

'I consider Mary innocent.'

(Snezana Jovanović, p.c.)

On a par with Romance languages such as Italian and Spanish, in European Portuguese we obtain the same paradigm (Pilar Barbosa and João Costa, p.c.):

(21) Q: Quem consideras muito esperta?

whom consider-PRES.2.SG very clever-FEM.SG

'Whom do you consider very clever?' 

A': Considero muito esperta a Maria. consider-PRES.1.SG very clever-FEM.SG to Maria '*I consider very clever Maria'.
A": \#Considero a Maria muito esperta. consider-PRES.1.SG to Maria very clever-FEM.SG 'I consider Maria very clever'.
a Maria?
how consider-PRES.2.SG to Maria
'How do you consider Maria?'
A': Considero a Maria muito esperta.
consider-PRES.1.SG to Maria very clever-FEM.SG
'*I consider very clever Maria'.
A": \#Considero muito esperta a Maria consider-PRES.1.SG very clever-FEM.SG to Maria 'I consider Maria very clever'.

The discourse restriction in terms of the [topic - focus] order pattern is active in European Portuguese as well. It is important to emphasise that the topic part is identified as such via de-accenting, which is typical of topical elements (Costa 2010).

Within the Slavic family, we also find Russian and Ukrainian which instantiate the information structure-based alternations in argument SCs we are studying. Consider the contrast between the sentences in (23) and (24), where the SC pattern is [DP XP], and those in (25-26), where rearrangement has applied. The reordering in (25-26) is motivated by the information structure.

(23) Russian

a. Schitajy tvojo predlozenije ochen' original'nym. judge-PRES.1SG your proposal very original 'I judge your proposal very original.'
b. U nejo ulybka miagkaja. have-PRES.3SG the.smile soft 'He has the smile soft.'
c. Naxozu Ximenu ochen' krasivoj. find-PRES.1SG Jimena very beautiful-FEM.SG 'I find Jimena very beautiful.'

(24) Ukrainian
a. Vvazajy tvoje propovnennja dyze original'nym. judge-PRES.1SG your proposal very original 'I judge your proposal very original.' 
14 Ángel L. Jiménez-Fernández \& Vassilios Spyropoulos

b. Maje usmishku m'jaky. have-PRES.3SG the.smile soft 'He has the smile soft.'

c. Znaxodzu Ximenu duze garnoju. find-PRES.1SG Jimena very beautiful-FEM.SG 'I find Jimena very beautiful.'

(25) Russian
a. Schitajy ochen' original'nym tvojo predlozenije. judge-PRES.1.SG very original your proposal 'I judge your proposal very original.'
b. U nejo miagkaja ulybka. have-PRES.3.SG soft the.smile 'He has the smile soft.'
c. Naxozu ochen' krasivoj Ximenu. find-PRES.1SG very beautiful-FEM.SG Jimena 'I find Jimena very beautiful.'

(26) Ukrainian
a. Vvazajy dyze original'nym tvoje propovnennja. judge-PRES.1SG very original your proposal 'I judge your proposal very original.'
b. Maje m'jaky usmishku. have-PRES.3SG soft the.smile 'He has the smile soft.'
c. Znaxodzu duze garnoju Ximenu. find-PRES.1SG very beautiful-FEM.SG Jimena 'I find Jimena very beautiful.'

On the opposite side of this typology, we also find languages which pattern with English since they do not allow for the SC alternative orders discussed above. Such is the case of French. Though French is a Romance language, the behaviour of SCs is parallel to that of Germanic languages. More precisely, French does not allow for the rearrangement of SC members irrespectively of their discourse properties. It is absolutely impossible to have the equivalent of Spanish/Greek [XP DP] order in French (Alain Rouveret, p.c.):
(27) a. Je considère
Suzanne intelligente.
I consider- PRES.1SG Suzanne intelligent
b. ${ }^{*}$ Je considère intelligente Suzanne.
I consider- PRES.1SG intelligent Suzanne
'I consider Susan intelligent.'


In general, Germanic languages show a very fixed word order, blocking any type of rearrangement in argument SCs. Such is the case of Norwegian (28), German (29) and Afrikaans (30), as illustrated below:

(28) Norwegian

a. Vi oppfatter forslag-et ditt som veldig originalt. we perceive proposal-the your as very original

a'. ${ }^{*}$ Vi oppfatter som veldig originalt forslag-et ditt. we perceive as very original proposal-the your 'We perceive your proposal very original.'

b. Det uventede sviket gjorde venn-en min the unexpected betrayal make-PAST friend-the my mistenksom. distrustful

b'. *Det uventede sviket gjorde mistenksom ven-en the unexpected betrayal make-PAST distrustful friend-the min.

my

'The unexpected betrayal made my friend distrustful.'

c. Jeg anser Merete som veldig vakker.

I find Merete as very beautiful

c'. *Jeg anser som veldig vakker Merete.

I find as very beautiful Merete

'I find Merete very beautiful.' (Merete Anderssen, p.c.)

(29) German

a. Ich halte deinen Vorschlag für sehr originell.

I hold-PRES.1SG your proposal for very original

a'. *Ich halte für sehr originell deinen Vorschlag.

I hold-PRES.1SG for very original your proposal

'I hold your proposal very original.'

b. Die unerwarteten Austritte machten

the unexpected abandonments make-PAST.3SG

meine Freundin misstrauisch.

my friend distrustful

b'. *Die unerwarteten Austritte machten

the unexpected abandonments make-PAST.3SG

misstrauisch meine Freundin.

mistrustful my friend

'The unexpected abandonment made my friend distrustful.'

c. Ich finde Laura sehr hübsch.

I find-PRES.1SG Laura very beautiful

c'. *Ich halte sehrhübsch Laura.

I find-PREs.1.sGverybeautifulLaura

'I find Laura very beautiful.'

(Christoph Ehlers, p.c.) 
(30) Afrikaans

a. Ek beoordeel jou voorstel (as) baie oorspronklik.

I judge your proposal (as) very original

a'. ${ }^{*}$ Ek beoordeel baie oorspronklik jou voorstel.

I judge very original your proposal

'I judge your proposal very original.'

b. Ek vind Maria baie pragtig

I find Maria very beautiful

b'. ${ }^{*}$ Ek vind baie pragtig Maria

I find very beautiful Maria

'I find Maria very beautiful.'

(Theresa Biberauer, p.c.)

In this type of language, regardless of whether the SC subject is the focus, there is no reordering at all; otherwise the result is not acceptable. However, focus is again achieved by phonological devices, as in English. ${ }^{10}$

To conclude this section, it is safe to draw a classification of languages depending on whether information structure based rearrangement is possible. Type 1 includes languages such as English, French, German, Afrikaans and Norwegian, which resist reordering. Type 2 groups together languages such as Spanish, Greek, Italian, Portuguese, Serbo-Croatian, Russian and Ukrainian, which allow the kind of rearrangement under study.

\section{The topic interpretation of the SC subject: some evidence}

\subsection{Topichood and definiteness/specificity effects}

In this section we provide evidence in favour of the topic nature of the postverbal constituent in argument SCs. In this connection, it is a well-

\footnotetext{
${ }^{10}$ Interestingly, in the evolution of Germanic languages the pattern [XP DP] is also well attested. As Christer Platzack (p.c.) points out to us, Older Swedish (roughly 1400-1700) usually had the small clause word order [DP XP] as in modern Swedish, English etc, but also occasionally had the order [XP DP], as in the following examples (with verbal SCs):
}

(i) ok thädan saa iak nidhir fara eet lius [15th c.]

and therefrom saw I down go a light

(modern Swedish must have 'saw I a light go down')

(ii) ta skal han läta fara präst sin

then shall he let go priest his

(it must be 'let his priest go' in modern Swedish)

For more details about this structure from a historical point of view, see Platzack (1986). 
known fact that topics, as opposed to foci, show Definiteness/Specificity effects $^{11}$ (Enç 1991; Erteschik-Shir 1997, 2006; Diesing 1992, 1997; Jayaseelan 2001; Molnár 2006; Leonetti 2004, 2008; Aguiar \& Rodrigues 2008; Aboh 2010; Frascarelli 2007). ${ }^{12}$ Before proceeding any further, in order to get a better understanding of the Definiteness effects in SCs, we first present some general aspects on the notion of Definiteness in its relation to topics. Although this is an extremely controversial issue, a Definiteness/Specificity constraint on topics is attested in many languages. Aguiar \& Rodrigues (2008) provide examples in English and Brazilian Portuguese which support the claim that topics are always definite/specific:

(31) a. *A student, I will see at LSRL (Linguistic Symposium on Romance Languages).

b. *Some/any/many student(s), I will see at LSRL.

c. *Alguns/ nenhum/muitos aluno(s), eu vou ver no LSRL. some/ no/ many student(s), I will see at.the LSLR 'I will see some/no/many student(s) at the LSLR.'

However, it is also reported that at least in Brazilian Portuguese some quantified DPs can occur in topic position if they contain a restrictive modifying element, as in (32a) (see Aguiar 2007 for data and a theory of quantified expressions as topics in Brazilian Portuguese).

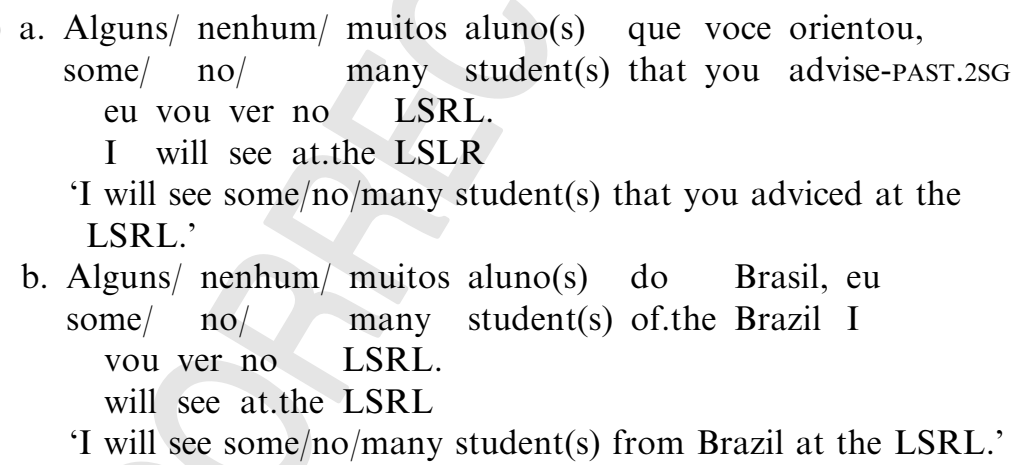

The explanation that Aguiar \& Rodrigues (2008) offer is that definiteness is expressed in languages by a (non-)definite feature in the structure of DPs

\footnotetext{
${ }^{11}$ Definiteness instantiates cross-linguistically in many ways: an article (English, Spanish), a suffix (Romanian), or even a prefix (Arabic). Some languages (Turkish) have been claimed to use case marking to distinguish between definiteness and indefiniteness (the distinction in Turkish is between specific and non specific, so that only specific objects, including indefinite specifics, are marked with accusative). Aljiović (2002) reports that in Serbo-Croatian a specific suffix is attached to prenominal adjectives to indicate the definiteness of the whole DP. Regarding all these possibilities, see Lyons (1999).

12 Actually, some of the above mentioned linguists have established a close relation between the notions of specificity and discourse linking and presupposionality (Enç 1991).
} 


\section{8 Ángel L. Jiménez-Fernández \& Vassilios Spyropoulos}

and some DPs change this feature for different reasons. In particular, in the above examples the presence of the modifying phrases within the indefinite DPs forces a definite reading of the relevant quantified DPs (in the sense of Keenan and Stavi 1986). ${ }^{13}$ In our view, there is no need to postulate a change in the feature composition of DPs because some indefinites are ambiguous; hence both readings are possible (see below).

Furthermore, an appropriate context may trigger a definite reading of indefinite DPs, which may support the idea of a coercing mechanism changing the definite feature of DPs. Examples in (33) illustrate this point (Aguiar \& Rodrigues 2008): ${ }^{14}$

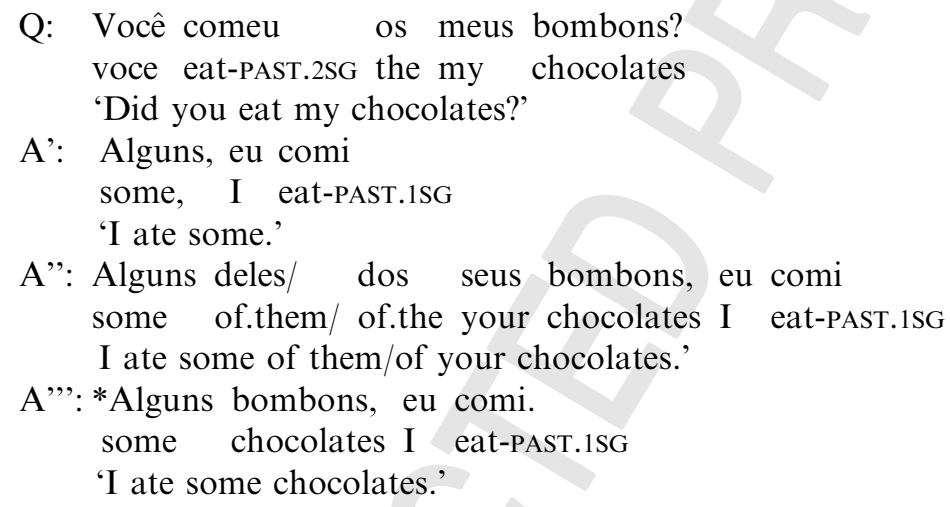

Interestingly, the definite reading of indefinites is best viewed in light of the distinction between definite and specific (Suñer 2003, Frascarelli 2007, İssever 2003). Indefinites are ambiguous in that they can have a specific or non-specific reading. All the indefinite DPs which can qualify as topics are specific. The crucial feature, thus, is specificity. Hence, the examples in (33A') and (33A") are predicted to be correct because the pre-posed indefinite topics are specific (Alexopoulou \& Folli 2011).

In Spanish there is also a general constraint on the specific/definite nature of topics to the effect that indefinite DPs are not generally picked up as topics, except if there is a trigger forcing a definite interpretation. This accounts for the marginal status of sentences such as (34):
?Algunos bombones, me he comido. some chocolates CL1-SG have-PRES.1SG eaten 'I have eaten some chocolates.'

\footnotetext{
${ }^{13}$ See Costa \& Figueiredo (2006) for the interaction of definiteness, givenness and quantification as being the actual precondition for topichood.

${ }^{14}$ Some kind of contrast is felt in all the examples in (33), which is indicative that the moved constituent stands for a contrastive topic. See Molnár (2006) for a recent treatment of contrast in its relation to other core functions of information structure such as topic and focus. A stronger claim is made by Bianchi \& Frascarelli (2010), who hold that dislocated topics of this type are always contrastive.
} 
This sentence is correct only if the indefinite DP algunos bombones has an antecedent in the previous discourse, i.e. if it is specific. If pronounced out of the blue, (20) is not felicitous. ${ }^{15}$

Dealing with Hungarian, É. Kiss (2002: 11) claims that topics must contain a $[+$ specific] feature. In this respect, Hungarian instantiates the kind of language which permits indefinites to be topicalized, as in (35):

a. Valaki top kopog. somebody knock-PRES.3SG

'Somebody is knocking.'
b. Valami top le esett
a tetorol.
something VM fall-PAST.3SG the roof
'Something has fallen from the roof.'

É. Kiss (2002) argues that these sentences containing indefinites valaki and valami are adequate only if their referent is present in the universe of discourse. For instance, (35a) is correct in a context where we have heard somebody knocking on the door. In other words, it seems that what definite and indefinite DPs share is a [+specific] feature in the sense of Enç (1991), that is, the reference of the relevant DPs has to be somehow presupposed. This is also the conclusion arrived at by İssever (2003) for Turkish, at least partially, since for him Turkish offers examples in which topics can also be realised by non specific elements. ${ }^{16}$

In Greek object topics are obligatorily marked with a doubling clitic (Philippaki-Warburton 1985, 1987, and many others thereafter): ${ }^{17}$

$$
\begin{aligned}
& \text { Q: pjos filise ti maria } \\
& \text { who-NOM kiss-PAST.3SG the Mary-ACC } \\
& \text { 'Who kissed Mary?' } \\
& \text { A: ti maria, *(ti) filise } \quad \text { o janis } \\
& \text { the mary-ACC CL3-FEM.SG.ACC kiss-PAST.3SG the John-NOM } \\
& \text { 'Mary was kissed by John'. }
\end{aligned}
$$
A: ti maria,
filise
o janis
the mary-ACC CL3-FEM.SG.ACC kiss-PAST.3SG the John-NOM
'Mary was kissed by John'.

The definiteness/specificity constraint applies as well, meaning that indefinite topics are generally disallowed. They are only acceptable if the context allows them to be interpreted as specific. Thus, the corresponding

\footnotetext{
${ }^{15}$ A contrastive reading of this sentence is also possible, implying a correction or contrast with respect to a previous assertion such as Os habéis comido todos los bombones, ¿no? 'You have eaten all my chocolates, haven't you?'.

${ }^{16}$ Kornfilt (2003) detects a connection between specificity and case in Turkish. She claims that specificity effects are not independent of other syntactic principles, such as the Condition on Extraction Domains.

${ }^{17}$ In Spanish and Italian, we find instances of familiar topics (see above) that are not resumed by a topic. Note that it is just with familiar topics. Givenness and D-linking are the major properties of this type of topics.
} 


\section{0 Ángel L. Jiménez-Fernández \& Vassilios Spyropoulos}

Greek examples of (36) are grammatical, only when the topic is clitic doubled and specific: ${ }^{18}$

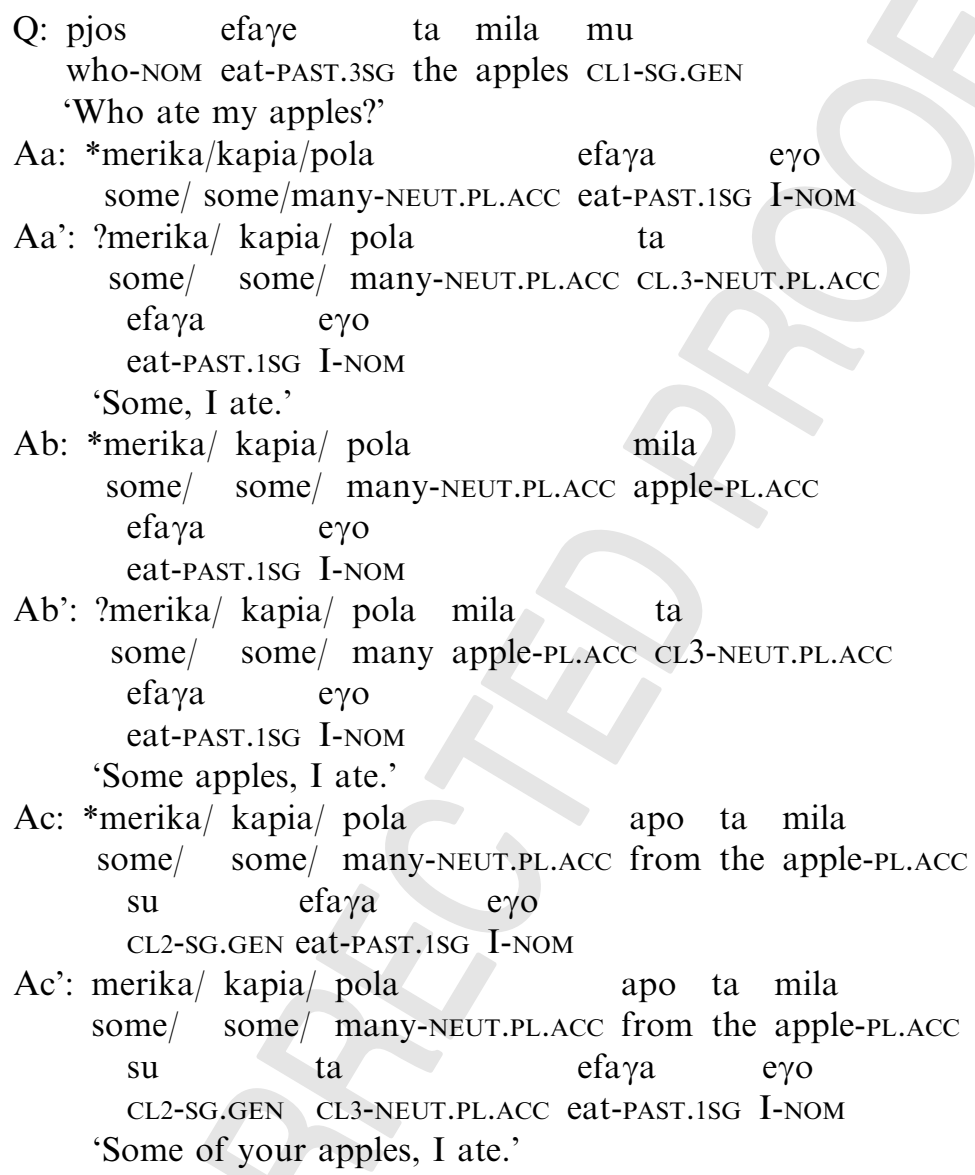

Ac: *merika/ kapia/ pola apo ta mila some/ some/ many-NEUT.PL.ACC from the apple-PL.ACC su efaya eyo CL2-SG.GEN eat-PAST.1SG I-NOM

Ac': merika/ kapia/ pola apo ta mila some/ some/ many-NEUT.PL.ACC from the apple-PL.ACC su ta efara e ro CL2-SG.GEN CL3-NEUT.PL.ACC eat-PAST.1SG I-NOM 'Some of your apples, I ate.'

However, specificity alone does not seem to be the only factor inducing topicality. Consider the following dialogue taking place in a tavern. A guy joins the party of other friends and he is asked whether he wants anything to drink:

${ }^{18}$ In Spanish we may also have an indefinite DP such as algunos estudiantes 'some students' in CLLD. In this case, the dislocated DP it is interpreted as specific (Suñer 2003), which means that these students either have been mentioned before or they are perfectly identified in context:

(i) A algunos estudiantes los veré en Leeds.

to some students CL see-PRES.1SG in Leeds

'I'll see some students in Leeds.'

The interpretation for this is that people in the conversation are aware of which students we are talking about. Note that $\mathrm{P} a$ 'to' for animate DP objects is inserted with a [+specific] reading (see below for discussion). 
(38)

$$
\begin{aligned}
& \text { Q: ti } \text { ti pjis? } \\
& \text { what FUT drink-2SG } \\
& \text { 'What do you want to drink?' }
\end{aligned}
$$
A: ena uzaki $\theta$ a to
epina
a ouzo FUT CL3-NEUT.SG.ACC drink-PAST.1SG
'I could drink an ouzo.'

In such a context, the indefinite ena uzaki 'an ouzo' is discourse prominent in the sense that you are expected to drink ouzo in a tavern (Kazazis \& Pentheroudakis 1976, Philippaki-Warburton 1987). In order to account for such facts Anagnostopoulou \& Giannakidou (1995) propose a discourse prominence condition based on D-linking à la Pesetsky (1987). There is a lot of discussion in Greek literature about the nature of this discourse prominence, but it seems to be connected with a very loose notion of givenness, where given is defined in terms of linguistic or extralinguistic context or in terms of pragmatic conditions, etc. (see the discussion in the references above and in Anagnostopoulou 1994, 1999, Androulakis 2001, 2010 among others). This givenness explains why a sentence such as (38A) is felicitous in the specific tavern context. ${ }^{19}$

To sum up, it seems that some interface conditions may have an influence on the specific interpretation of an indefinite DP. These interface conditions are D-Linking (either linguistic or contextual) and givenness. Candidates for topicality must contain the feature [+ specific].

In Spanish a connection is found between specificity and what has been called differential object marking. In this language the direct object is introduced by the preposition $a$ if the relevant DP is interpreted as specific (Leonetti 2004). This explains the difference between the two sentences in (39):
a. Necesita
a una enfermera que pasa
need-PRES.IND.3SG to a nurse
la mañana con ella.
the morning with her
b. Necesita una enfermera que pase
need-PRES.IND.3SG a nurse that spend-PRES.SUBJ.3SG
la mañana con ella.
the morning with her

'He needs a nurse \{that spends the morning with her / to spend the morning with her\}.'

\footnotetext{
${ }^{19}$ In Spanish indefinite given DPs can be used with or without a clitic in a similar context:
(i) Una cerveza me (la) tomaba yo.
A beer CL.1-SG CL.3-FEM.SG drink-PAST..1SG I
'I would love a beer.'




\section{2 Ángel L. Jiménez-Fernández \& Vassilios Spyropoulos}

The point that we are especially interested in is that if topicalizable DPs contain the feature [+specific], animate bare DP objects are predicted not to occur in topic position. This is confirmed by the contrast between (40a) and (40b) (Leonetti 2004): ${ }^{20}$
a. A muchos estudiantes, ya
los conocía
to many students already
CL.3-PL knOW-PAST.1SG
'Many students I already knew'.
b. *Muchos estudiantes, ya los conocía many students, already CL.3-PL know-PAST.1SG 'Many students I already knew'.

From the paradigm in (40) it follows that, at least in languages such as Spanish, specificity, topicality and the prepositional marker $a$ are closely related in such a way that animate topics tend to be specific and prepositional.

The conclusion so far seems to be that candidates deemed as topics must be specific, either by nature or as a consequence of some linguistic or contextual strategy forcing a specific reading of indefinite DPs. ${ }^{21}$

The preceding remarks posit an intriguing question as far as the information structure of SCs is concerned: Does the syntax of SCs give rise to any specificity effects? Our immediate task is to explore the interplay between specificity and topichood in argument SCs. The basic idea is that topics should contain a [+specific] feature which entitles possible candidates as suitable to be topicalized. On the other hand, foci can either be specific or non specific. If this is on the right track, we should expect a possible non-specific focus in the SC subject position, but

\footnotetext{
${ }^{20}$ See also Laca (1987), who argues that in clitic left dislocation the preposition is always present regardless of its possible absence in their non-dislocated counterparts.

${ }^{21}$ In principle, a special status should be kept for generic DPs. According to Zubizarreta (1998) and Moreno \& Pérez (2004), in Spanish left dislocated bare plurals can be interpreted as topics:
}

(i) Manzanas, Pedro (las) come todos los días.

Apples Peter CL3-PL eat-PRES.3SG all the days

'Apples, Pedro eats them every day.'

In Greek, bare plural generics are the only ones that may be topicalized without a clitic; in fact they do not tolerate a clitic. On the contrary, definite plural generics can be topicalized only when they are clitic doubled/dislocated.
(ii)
mila, $\quad 0$ janis troi apple-PL.ACC the John-NOM eat-3SG
b. *mila,
o janis ta
kaقe mera
every day
apple-PL.ACC the John-NOM CL3-NEUT.PL.ACC eat-3SG every day 'Apples, John eats them every day.'
(iii) a. *ta skilakia, ta peðia latrevun
the puppy-PL.ACC the child-PL.NOM adore-3PL
b. ta skilakia, ta peðia ta latrevun
the puppy-PL.ACC the child-PL.NOM CL3-NEUT.PL.ACC adore-3PL
'Puppies, children adore them.'


never a non-specific topic. This prediction is borne out in the light of examples in (41) and (42):
a. */?? Dejamos
muchos cubiertos
limpios. $^{22}$
leave-PAST.1PL many pieces of cutlery-MSC.PL clean-MSC.PL
b. Dejamos limpios muchos cubiertos.
leave-PAST.1PL clean-MSC.PL many pieces of cutlery-MSC.PL
'We left many pieces of cutlery clean.'

(42)
a. */??Considero
algunos asuntos
claros.
consider-PRES.1PL some
affairs-MSC.PL clear-MSC.PL
b. Considero claros
algunos asuntos
consider-PRES.1PL clear-MSC.PL some affairs-MSC.PL
'I consider some affairs clear.'

The data in (41-42) can be accommodated in terms of the topic - focus partition of the SC. The DPs muchos cubiertos 'many pieces of cutlery' and algunos asuntos 'some affairs' can be the subject of an SC only when they are interpreted as foci, as in (41b) and (42b), but their occurrence (with the intended topic interpretation) is circumscribed to the [AP DP] pattern. Note that the SC subject contains a [-specific] feature which does not favour a topic reading, explaining the anomaly of (41a) and (42a). If the SC indefinite subject is replaced by a definite DP the anomaly vanishes:
a. Dejamos
todos esos cubiertos
limpios.
leave-PAST.1PL all those pieces of cutlery-MSC.PL clean-MSC.PL
b. Dejamos
limpios
todos esos cubiertos.
leave-PAST.1PL clean-MSC.PL all those pieces of cutlery-MSC.PL 'We left all those pieces of cutlery clean.'

As is clear, with a specific subject both the patterns [DP AP] and [AP DP] are fully acceptable. The contrast between (41a) and (43a) indicates that the post-verbal slot is a topic position which can only be filled by a

\footnotetext{
${ }^{22}$ The ungrammaticality/inappropriateness of these examples is crucially dependent on the non-specific interpretation of the SC subject. In languages such as Spanish indefinite DPs are ambiguous between a specific and a non-specific reading. If these DPs are interpreted as specific, the examples improve considerably since they can be topics (see note 19).
} 


\section{4 Ángel L. Jiménez-Fernández \& Vassilios Spyropoulos}

definite/specific DP. ${ }^{23}$ Building on Leonetti's (2004) claim that personal $a$ is only compatible with specific DPs, it is interesting to test the possible occurrence of (non)specific animate DPs in the topic position detected for the SC subject in the pattern [DP XP]. If topics are specific, and prepositional animate objects (and subjects) are specific, it is expected to find examples of SCs containing a prepositional animate subject, whereas non-prepositional animate subjects are predicted not to be licensed in the relevant sequence. The examples in (44) confirm this prediction:

(44) a. Encuentro a la/ esta señora muy elegante. find-PRES.1SG to the/ this lady very elegant 'I find the/this lady very elegant.'

b. *Encuentro la/ esta señora muy elegante. find-PRES.1SG the/ this lady very elegante 'I find the/this lady very elegant.'

The contrast in (44) may receive a principled explanation only if the postverbal position is defined as a topic.

That the post-verbal position is reserved for a topic element is also evident from the following example from Greek.

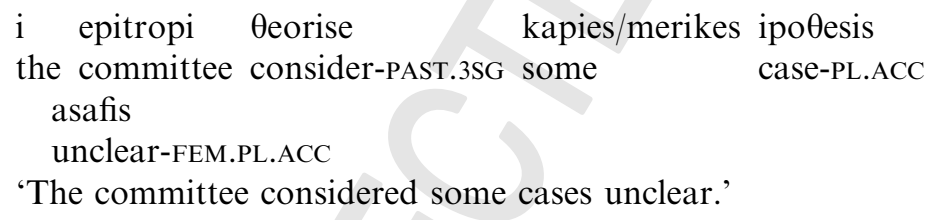

'The committee considered some cases unclear.'

Although constructions with indefinite SC subjects are grammatical/ felicitous when pronounced out of the blue, they are disallowed when the indefinite SC subject constitutes a topic. The only chance for an indefinite $\mathrm{DP}$ to function as the SC subject with a topic reading is when it is clearly specific $(46 \mathrm{Ab})$.

$$
\begin{aligned}
& \text { Q: ti rnomi ixe } \quad \text { i epitropi } \quad \gamma \text { ja tis } \\
& \text { what opinion have-PAST.3SG the committee-NOM for the }
\end{aligned}
$$

'What was the opinion of the committee about the cases?'

\footnotetext{
${ }^{23}$ The coercing strategy that turns a [-specific] feature into a [+specific] one ameliorates the judgement about examples such as (41a) and (43a). This implies that if a modifier is inserted in the relevant DP or simply the context forces a specific reading, these sentences are licit, and the post-verbal DP allows for the usual topic reading:

(i) Dejamos muchos de esos cubiertos limpios.

leave-PAST.1PL many of those pieces of silverware clean

'We left many of those pieces of silverware clean.'
} 


$$
\begin{array}{cll}
\text { Aa: } & *_{i} \text { epitropi } \quad \text { enorise } & \text { kapies/merikes } \\
\text { the committee consider-PAST.3SG } & \text { some } \\
\text { ipo } \theta \text { esis asafis } & \\
\text { case-PL.ACC } & \text { unclear-FEM.PL.ACC } &
\end{array}
$$

'Some cases, they considered them unclear.'

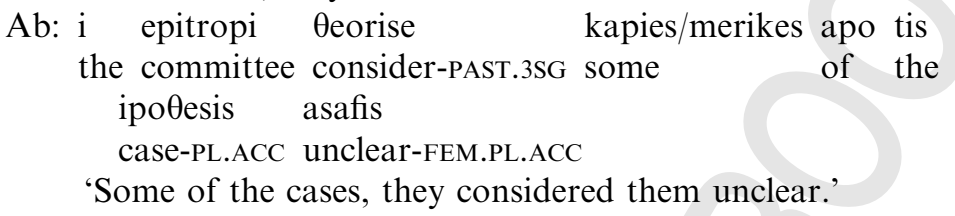

As shown by the paradigm in (46), Greek also instantiates a clear preference for topics which are marked as [+specific]. This accounts for the difference between (46Aa) and (46Ab), where the specific DP kapies/merikes apo tis ipotesis 'some of the cases' is used and the topic reading is available.

\subsection{Two other pieces of evidence for topichood}

Additional support for the topic nature of the post-verbal element of argument SCs comes from contextual considerations. The following text has been extracted from a context where two twin girls are compared:

(47) Pero en el de Linda había una serenidad y una tranquilidad que contradecían con la vivacidad de su hermana y que realmente la hacían a ella más atractiva. 'But in Linda's there was a serenity and a tranquillity which contradicted her sister's liveliness and which really made her more attractive.'

Frascarelli (2007) claims that overt subjects in Romance are used only if they are topic or focus. In the context in (46) the information provided by the SC subject a ella is shared in the communicative environment; more strictly, the information provided by this constituent is given in discourse. Accordingly, it stands as a familiar topic, to use Frascarelli \& Hinterhölzl's (2007) term. As such it cannot occur in final position, which is typically reserved for information focus, as (48) suggests:

$$
\begin{aligned}
& \text { (48) \#... y que realmente la hacían más atractiva a } \\
& \ldots \text { and which really CL make-PAST.3PL more attractive to } \\
& \text { ella. } \\
& \text { her } \\
& \text { '... and which really made her more attractive.' }
\end{aligned}
$$

This unavailable reordering lends further support to our claim that the first SC constituent after the matrix verb is placed in a topic position.

Finally, we present a last piece of evidence which supports the topic nature of the post-verbal DP in SCs; namely, the interaction of floating quantifiers (FQs) and the discourse properties of the SC. Valmala (2008) 


\section{6 Ángel L. Jiménez-Fernández \& Vassilios Spyropoulos}

proposes that the reason why the FQ phenomenon exists is that there is a mismatch in the discourse features of the FQ and its associate. What this means is that for the possible combinations of topic marking, focus marking or no marking (hence neutral), it is only when the marking of the quantifier and its associate does not coincide that the dissociation is produced, inducing FQ. This explains the different combinations attested in Spanish, some of which are exemplified in (49):
a. Los estudiantes de física creo que the students of physics think-PRES.1SG that TODOS consiguieron beca. all get-PAST.3PL grant
b. LOS ESTUDIANTES DE FÍSICA creo que consiguieron todos beca.
c. Los estudiantes de física creo que consiguieron todos BECA. 'I think that all students of physics got a grant.'

In (49a) the moved DP los estudiantes de física 'the students of physics' is marked as a topic, whereas the FQ todos 'all' is marked as a contrastive focus. Conversely, in (49b) the moved DP is a contrastive focus, whereas the FQ is neutral. Moreover, in (49c) the moved DP has a topic function, and the stranded FQ is neutral.

As stated above, the SC pattern [DP XP] reflects two possible discourse interpretations: i) the DP subject is a topic, and ii) the DP subject is an insitu contrastive focus. ${ }^{24}$ In the light of Valmala's (2008) possible combinations of FQ and its associate, the prediction is that the DP is dissociated from the $\mathrm{Q}$ in SCs when each has a different discourse marking. This is confirmed by examples in (50), which illustrate the combination of a neutral FQ and a topic associate:
a. Encuentro estos libros todos interesantes. find-PRES.1SG these books all interesting 'I find all those books interesting.'
b. Encuentro a los chicos todos muy traviesos. find-PRES.1SG the boys all very naughty 'I find all the boys very naughty.'

Turning into Greek, the examples in (51) shows a clear parallelism:

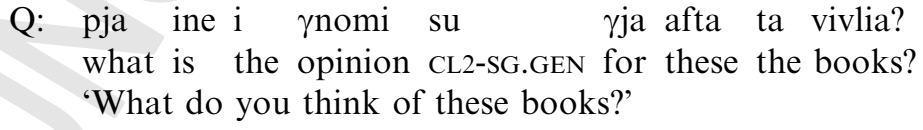

\footnotetext{
${ }^{24}$ For the sake of completeness, we mention that this is the order with a neutral reading in wide scope cases.
} 
Aa: afta ta vivlia ta $\quad$ Oeoro

these the books CL3-NEUT.PL.ACC consider-1SG ola enðiaferonta.

all-NEUT.PL.ACC interesting-NEUT.PL.ACC

Ab: Aeoro ola afta ta vivlia

consider-1SG all-NEUT.PL.ACC these the books enðiaferonta

interesting-NEUT.PL.ACC

Ac: ?*Aeoro afta ta vivlia ola

consider-1SG these the books all-NEUT.PL.ACC

enðiaferonta

interesting-NEUT.PL.ACC

Ac': Aeoro afta ta vivlia OLA

consider-1SG these the books all-NEUT.PL.ACC enðiaferonta

interesting-NEUT.PL.ACC

'I consider all these books interesting.'

(51Aa) with clitic left dislocation and FQ in situ is the most preferred answer by far. FQ may be interpreted as neutral or focal. (51Ab) is also a felicitous answer, although less favoured and unnatural compared to (51Aa). Interestingly, splitting the FQ post-verbally (51Ac) gives a nonfelicitous answer, unless the FQ is contrastively focused (51Ac'). This verifies our claim that the DP has moved out of the VP due to its topic reading. ${ }^{25}$

However, when the associate is marked as a contrastive focus it cannot co-occur with the FQ. One plausible explanation lies in that the FQ in these contexts does not differ in its discourse marking from its associate. Accordingly, both FQ and associate are marked as contrastive foci; hence the split is barred, as justified in the examples in (52-53):

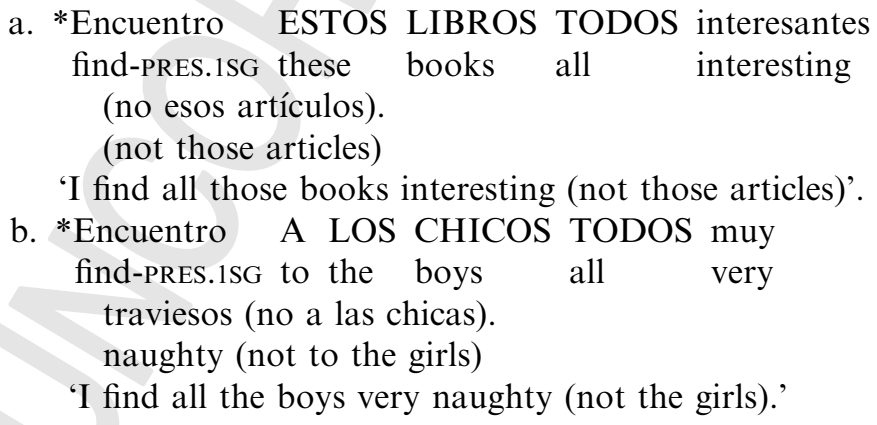

a. *Encuentro ESTOS LIBROS TODOS interesantes find-PRES.1SG these books all interesting (no esos artículos). (not those articles)

'I find all those books interesting (not those articles)'.

b. *Encuentro A LOS CHICOS TODOS muy find-PRES.1SG to the boys all very traviesos (no a las chicas). naughty (not to the girls)

'I find all the boys very naughty (not the girls).'

\footnotetext{
${ }^{25}$ However, the fact that splitting a neutral FQ in (50Ac) also gives a non-felicitous answer may indicate that the DP is conceived somehow as neutral. We have no explanation of this fact at the moment.
} 
(53) a. Encuentro TODOS ESTOS LIBROS interesantes (no esos artíc ulos).

b. Encuentro A TODOS LOS CHICOS muy traviesos (no a laschi cas).

As the examples in (53) illustrate, the occurrence of the FQ todos with no dissociation of its associate is licit, which accounts for the contrastive focus flavour detected in SCs conforming to the pattern [DP XP]. The same situation holds in Greek:

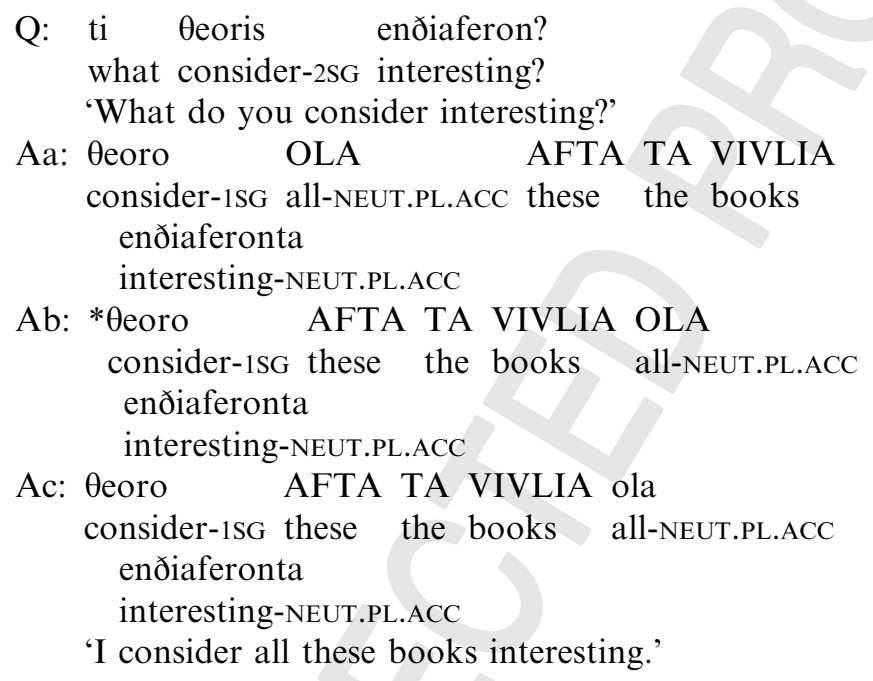

The only difference is that, when the FQ is left behind, it has to be interpreted either as neutral or as topic depending on the context. These facts indicate that the DP with the contrastive focus reading has moved out the SC constituent, perhaps to a position in the VP, in order to satisfy a [focus] feature. Moreover, the fact that the FQ is not part of the $\mathrm{CF}$ gives further credit to the dissociation property of the SC DP-subject and its FQ.

As a conclusion, the [topic - focus] partition can accommodate all the data that we have discussed in this section. The specificity constraint on the SC subject supports the topic nature of this constituent. Moreover, the distribution of FQs lends further credit to our proposal that the SC subject may be an embedded topic. ${ }^{26}$

\section{A feature-inheritance analysis of SCs: movement to Spec-VP}

In this section we propose that the word order differences identified in SCs can be accounted for in a principled way if the behaviour of phasal $v$ in a

\footnotetext{
${ }^{26}$ See Jiménez-Fernández (forthcoming) for additional arguments in favour of the [topic focus] analysis of SCs in Spanish.
} 
specific language is parallel to that of C. Miyagawa $(2005,2010)$ holds that $\mathrm{C}$ enters the Lexicon with discourse features ( $\delta$-features), which may be inherited by $\mathrm{T}$ depending on the relevant language. We take a step further and claim that a similar behaviour is detected in the $v \mathrm{P}$-area. This syntactic strategy is also subject to parametric variation. In our system, English is thus predicted not to allow for rearrangement in SCs, whereas Spanish and Greek are expected to permit such reordering. The permutations detected in such languages are crucially contingent upon the discourse properties of SCs. By combining the inherited $\delta$-feature and an edge feature $(\mathrm{EF}), \mathrm{V}$ attracts the SC topic part to spec-VP, be it the subject or the predicate, hence accounting for the reordering of subject and predicate.

There have been many competing analyses of SCs proposed (Stowell 1981, Kitagawa 1985, Aarts 1992, Bowers 1993, 2001, Den Dikken 2006, Citko 2008, 2011, among many others; see also Jiménez-Fernández 2000, 2002, forthcoming for Spanish and Spyropoulos 1998, 1999 and Tsokoglou 1997 for Greek). Assuming that SCs are not fully fledged sentences, ${ }^{27}$ we will deduce that they do not contain either a $\mathrm{C}$ or the corresponding Topic and Focus categories identified in the CP-system by the cartographic studies. ${ }^{28}$ This leaves the possibility of detecting discourse positions at a lower zone, as Belletti (2004), Aboh (2007) and Zubizarreta (2010) propose. Claiming that concrete discourse categories will account for discourse movement is far beyond Economy Principles. However, given the discourse interpretation of the members of SCs in

\footnotetext{
${ }^{27} \mathrm{We}$ assume that $\mathrm{SC}$ structure includes a functional projection $\mathrm{F}$ (much in line with Cinque 1990 and Haegeman 2010) above the projection of the category that functions as the predicate, the exact content of which is not clear. For the possibility of including other functional categories in the structure of SCs, see Jiménez-Fernández (2000), who claims that SCs project an Aspectual Phrase; Bowers (1993, 2001), who posits a Predicate Phrase above the SC; Starke (1995), who holds that SCs are full clauses and hence project a CP. For reasons of space we cannot discuss the different proposals and remain neutral with respect to the exact status of the functional spine of SCs. Thus SCs are analysed here as FPs (functional projections). However, we note that SCs are reduced clauses, and hence lack a $\mathrm{CP}$. One of the main motivations for this is that $\mathrm{CP}$ is in charge of endowing clauses with illocutionary force, thereby typing clauses as declarative, interrogative, exclamative, etc. It is obvious that SCs do not convey any force since they cannot be described as declarative, interrogative, etc. From this it follows that SCs are not CPs.

With respect to our theory of SCs, there have been two main lines of research of SC within generative grammar. For some linguists (all the above-mentioned authors), SCs are syntactic units of some kind. For other linguists, such as Williams (1983 et seq.) and Rothstein (1985), the predicate of the SC is predicated of its subject constituent, and hence these two elements need not constitute a constituent. This is known as the Predication Theory (Williams 1980). We take the first line of research as superior. Again, lack of space precludes a thorough discussion of this point here, but one of the arguments against the predication theory is, in our view, that if argument SCs do not constitute a syntactic unit, there is no possible way to distinguish between argument SCs and adjunct SCs (secondary predicates).

${ }^{28}$ See Erteschik-Shir (2006) and Neeleman \& van de Koot (2008) for arguments against Rizzi's $(1997,2004)$ idea that Focus and Topic are heads that project their own phrases. Also, Gill \& Tsoulas (2004) provide an extensive study of discourse effects in the clause without specific discourse-related categories at the edge of phases.
} 
some languages, we propose that the matrix $v \mathrm{P}$-area in those languages is responsible for the interpretation of embedded constituents as topic or focus. The syntactic configuration for argument SCs and its projection into the matrix $v \mathrm{P}$ phase is as follows:

(55)

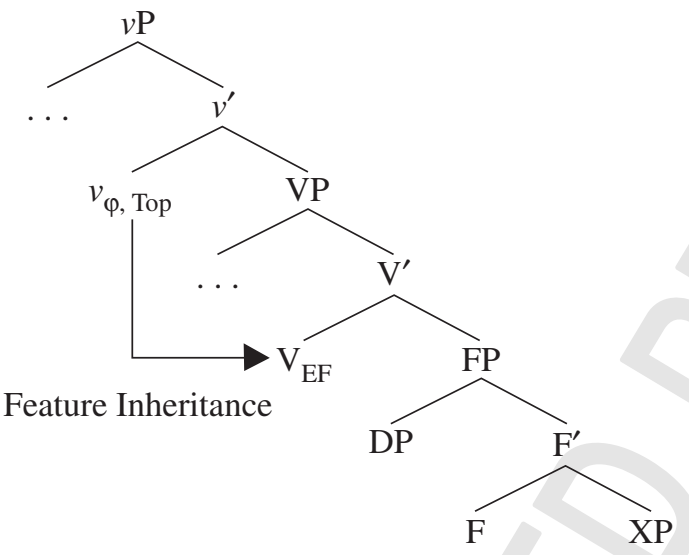

From the strict parallelism between the C-T and $v$-V systems it follows that feature inheritance also takes place in the lower phasal $v$. This basically corresponds to a parametric variation among languages, in that if the language is agreement prominent, it highlights the $\varphi$-features in the $v$-V system; but if the language is discourse prominent, it emphasizes its discourse features. This is in clear analogy with the C-T system, and, in line with Jiménez (forthcoming), the prediction is that those languages highlighting agreement features in $\mathrm{C}-\mathrm{T}$ also give prominence to agreement features in $v-\mathrm{V}$. On the contrary, if the language puts a special emphasis on discourse features in $\mathrm{C}-\mathrm{T}$, it will also give priority to discourse features in $v$-V. This proposal will explain the different behaviour of English and Spanish/Greek.

Starting with English, the SC in (56) will show the partial derivation in (57), where we concentrate just on the SC region:

(56) I find these books interesting. 
$(57)$

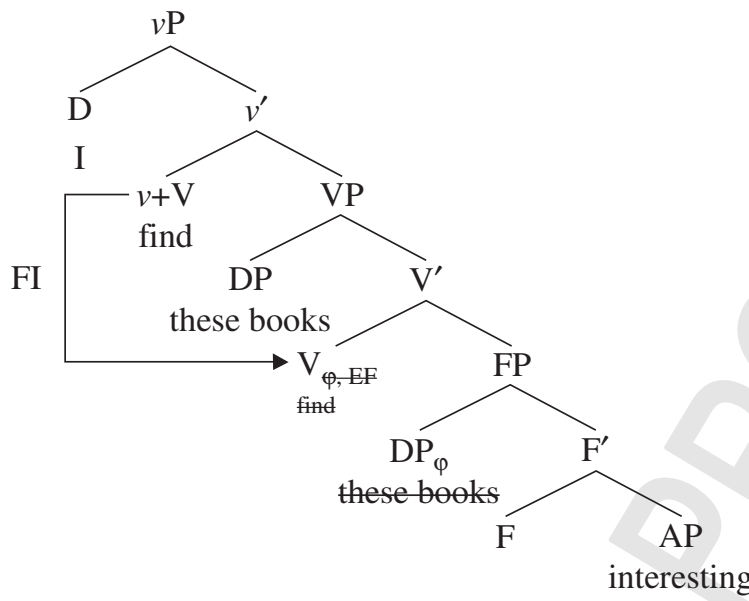

The first issue in this derivation is that little $v$ comes from the Lexicon with agreement features, $[u$-pers] and [ $u$-num] to be more precise. These $\varphi$-features percolate down to $\mathrm{V}$ in English and they will work in conjunction with the edge feature (EF) under $\mathrm{V}$, so that $\mathrm{V}$ will probe a suitable Goal. In its search, V finds the SC DP subject. Via AGREE the unvalued features of $\mathrm{V}$ are assigned the values [3-pers] and [pl-num] and the EF will attract the agreed-with category to Spec-VP. Given that V is subsequently raised to $v$ in English, the whole derivational process proposed accounts for the order [DP XP] in the SC. ${ }^{29}$ At the point of the $v \mathrm{P}$ phase's transfer into the semantic and phonological components the non-interpretable features under $\mathrm{V}$ are deleted.

If discourse features are not given prominence in English, the same pattern [DP XP] is predicted to fulfil the discourse needs in the SC. In terms of the topic - focus partition, sentence (56) maybe used as an answer for either (58) or (59):

(58) Q: What do you find so interesting?

A: I find these books very interesting.

(59) Q: How do you find these books?

A: I find these books very interesting.

In the absence of any syntactic device to establish a difference between topics and foci, it is the phonological component that will provide the necessary tools to do so. More precisely, if the embedded topic is a

${ }^{29}$ Note that raising the SC subject to Spec-VP can be traced back to Postal's (1974) subject-to-object raising in ECM constructions. Recently, Chomsky (2008) has stuck to Postal's original idea of raising. See also Lasnik \& Saito (1992), Lasnik (1999 et seq.) and Hong \& Lasnik (2010). 


\section{2 Ángel L. Jiménez-Fernández \& Vassilios Spyropoulos}

Familiar Topic, as we have proposed, the phonological strategy that English uses is de-stressing (Frascarelli \& Hinterhölzl 2007).

The other type of language that our proposal predicts is illustrated by Spanish and Greek, in which the rearrangement of the SC members depends on their discourse functions. To exemplify this discourse-related reordering, the derivations of (60-61) are provided in (62-63): ${ }^{30}$

(60) a. Encuentro estos libros interesantes.

b. vrisko afta ta vivlia enðiaferonta

(Spanish) find-1SG these the books-ACC interesting-NT.PL.ACC

(Greek)

(61) a. Encuentro interesantes estos libros.

b. vrisko enðiaferonta afta ta vivlia find-1SG interesting-NT.PL.ACC these the books-ACC

(62)

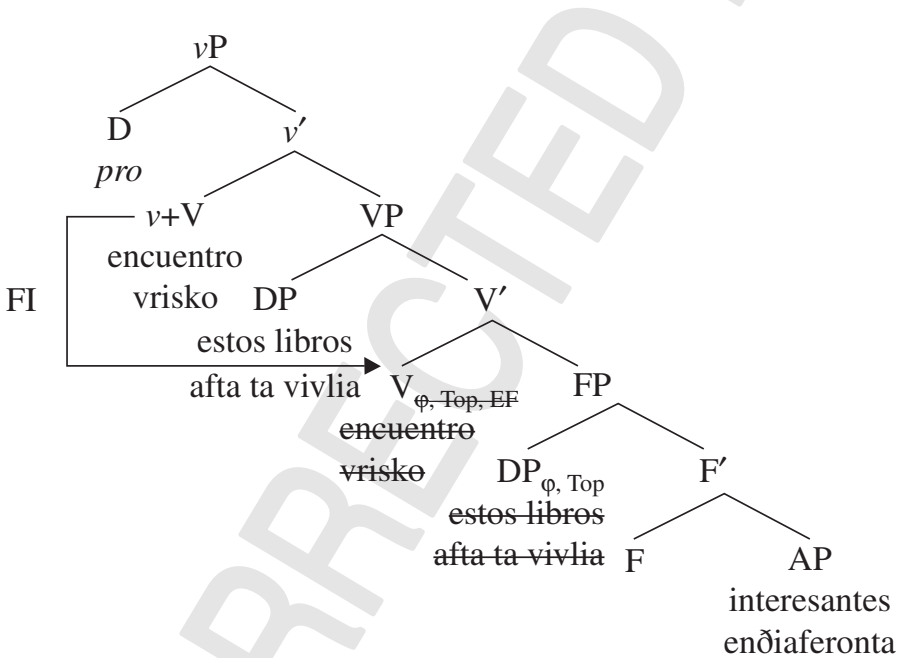

\footnotetext{
${ }^{30}$ In the derivations we are not taking into consideration that in languages like Spanish
} and Greek $\mathrm{V}$ raises to $\mathrm{T}$. 


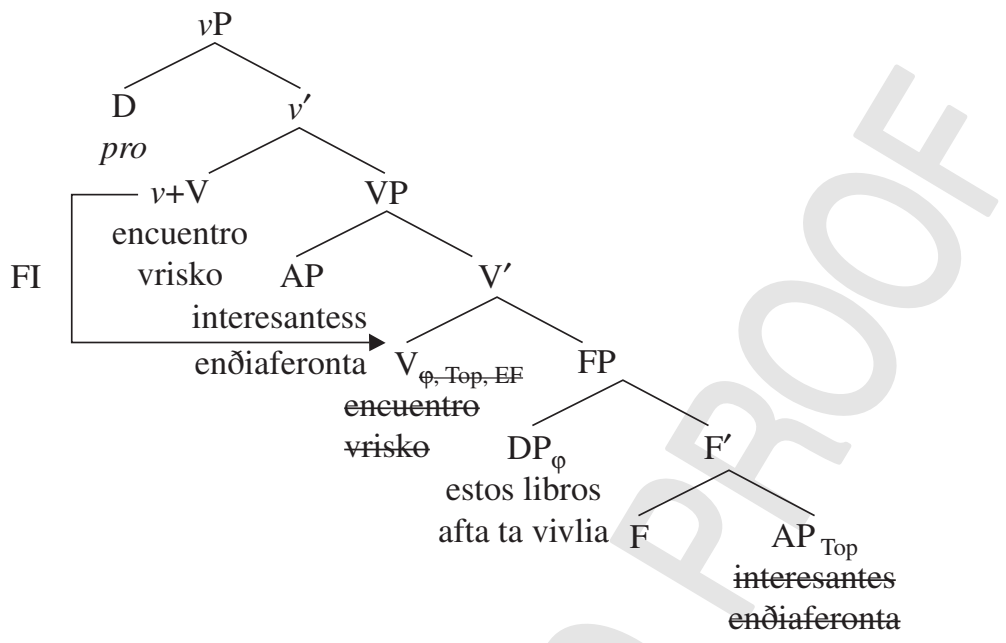

If Spanish and Greek are both agreement prominent and discourse prominent, it is because the two types of grammatical features at issue are given special prominence. Implementing Miyagawa's (2010) system, this implies that both $\varphi$-features and $\delta$-features are inherited by $\mathrm{V}$, which parallels the behaviour of the C-T system in Spanish, a welcome result. In (62) the EF works in tandem with all the inflectional features under V. If this is right, just by probing one single constituent the unvalued features will be assigned the values of the Goal, which in this case is the SC subject, thereby being attracted to the edge of VP.

By contrast, in (63) there is a dissociation of features, in such a way that the EF must work in conjunction with just the unvalued $\delta$-feature, which explains why when the SC predicate constitutes background information it is this constituent that is moved to the edge of VP, accounting for the preferred order [XP DP] in the relevant contextual situation. ${ }^{31}$ Evidence that the [XP DP] order is a derived one in Spanish contra Groos \& Bok-Bennema (1985) - comes from binding effects. Building on Ordoñez (1998) and Demonte (1995) works, binding effects are obtained in SCs only if it is accepted that XP is moved to the left of DP, so that $[X P D P]$ is not a basic order:

\footnotetext{
${ }^{31}$ Note that the type of discourse feature at issue corresponds to a familiar topic feature. Our analysis of familiar topics takes from Frascarelli \& Hinterhölzl (2007) the idea that they move to some position in the periphery, but it departs from their proposal in that they move to a designated FamP. Instead, familiar topics in Spanish and Greek move to Spec-VP after a specific $\delta$-feature is inherited by $\mathrm{V}$.

It should also be clear that the topic feature that we postulate in the VP area can either be satisfied by a topic proper or by background information. The latter is the case when the SC predicate moves to leave the subject in focus position, after Zubizarreta (1998). In this respect, the SC predicate conveys familiar information which is shared by all participants. It is not a topic in the sense of Reinhart (1981).
} 


\section{4 Ángel L. Jiménez-Fernández \& Vassilios Spyropoulos}

(64) a. Considero [a cada niño $]_{i}$ interesado en $\mathrm{su}_{\mathrm{i}}$ juego. consider-PRES.1SG to each child interested in his/her game

b. Considero interesado en $\mathrm{su}_{\mathrm{i}}$ juego [ a cada niño] $]_{\mathrm{i}}$. consider-PRES.1SG interested in his/her game to each child 'I consider each boy interested in his/her game.'

The reading of (64b) in which the pronoun $s u$ 'his/her' is interpreted as referring to each of the children is possible if the SC subject c-commands the pronoun. This implies that, originally, the SC predicate interesado en su juego 'interested in his/her game' is generated below the $\mathrm{SC}$ subject and then moves up to the matrix VP-area leaving a null copy behind. The same situation holds in Greek too:

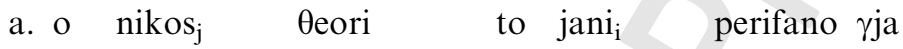 the Nikos-NOM consider-3SG the John-ACC proud for ton eafto $\mathrm{tu}_{\mathrm{i} /{ }^{\mathrm{j}} \mathrm{j}}$ himself

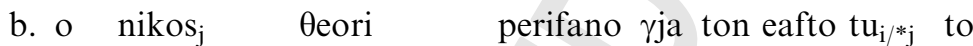 the Nikos-NOM consider-3SG proud for himself the jani $i_{i}$ John-ACC
'Nikos considers John proud of himself.'

The final question that arises in our discussion is, what about the $\varphi$ feature valuation? The dissociation of the features allows them to work separately from the $\delta$-features; thus the $\varphi$-features inherited by $\mathrm{V}$ probe the $\mathrm{SC}$ subject as a suitable goal. Since these features are not associated with the EF of V, they are valued via long-distance Agree with the SC subject.

\section{Summary and concluding remarks}

We have proposed a twofold typology of languages, based on the syntax/ discourse properties of SCs: English/French vs. Spanish/Greek. Unlike languages of the English/French type, in which the order of the SC constituents is fixed irrespective of the discourse properties, languages of the Spanish/Greek type allow for constituent order rearrangements depending on the discourse properties. These constituent order rearrangements and their corresponding discourse properties are the following:

(i) DP is neutral and XP is focus: [DP XP] order (no movement of either member is involved)

(ii) DP is topic and XP is focus: [DP XP] order (movement of DP to Spec-VP)

(iii) Contrastive Focus on DP: any order may be used.

(iv) Contrastive Focus on XP: any order may be used. 
(v) DP is informational focus: The most felicitous option is the [XP DP] order. If [DP XP] is used, a phonological strategy assigns IF to DP by means of a prominent stress. Here, some contrastive flavour is detected on DP, which may imply that IF and CF converge on DP.

(vi) When we are asked about the DP, we can also use the pattern [DP XP], but the XP seems to be right-dislocated. Since predicates are not marked with clitics, no clitic appears. In Greek this pattern cannot be used unless the DP is strongly emphasized).

(vii) When we are asked about the XP, we may also use the [XP DP] order, but the DP is right-dislocated and a clitic is used.

In order to account for these facts, we have put forward the hypothesis that in languages of the Spanish/Greek type, the $v$ head of the $v \mathrm{P}$ phase in which the SC is embedded carries discourse $\delta$-features alongside the $\varphi$ features and that both features are inherited by the $\mathrm{V}$ head. The $\delta$ features in conjunction with the edge feature of $\mathrm{V}$ attracts the element which functions as topic in Spec-VP, deriving the [topic - focus] pattern underlying the constituent order rearrangements observed in these languages. This way, $v \mathrm{P}$ phases are shown to behave like $\mathrm{CP}$ phases, which is a welcome result in the light of Chomsky's claim that there is a strict parallelism among phases.

\section{References}

AArTs, B. 1992. Small clauses in English: The nonverbal types. Berlin/New York: Mouton de Gruyter.

Авон, Е. O. Leftward focus versus rightword focus: the Kwa-Bantu Conspiracy. SOAS Working Papers in Linguistics 15:81-104.

Авон, E. O. 2010. Information structure begins with the numeration. IBERIA: an International Journal of Theoretical Linguistics 2:12-42.

Aguiar, A. C. 2007. Da estrutura de expressões nominais quantificadas em posição de tópico. University of Brasilia. Ph.D Thesis.

Aguiar, A. C. \& Rodrigues, C. 2008. The internal DP structure of topicalized quantified expressions. Paper presented at the 38th Symposium on Romance Linguistics, University of Illinois at Urbana-Champaign.

Alexiadou, A. 1999. Greek word order patterns. Studies in Greek syntax, eds. A. Alexiadou, G. Horrocks \& M. Stavrou, 45-65. Dordrecht: Kluwer Academic.

Alexopoulou, D. \& Folli, R. 2011. Indefinite topics and the syntax of nominals in Italian and Greek. WCCFL 28 Online Proceedings, ed. M. Byram Washburn, S. Ouwayda, C. Ouyang, B. Yin, C. Ipek, L. Marston \& A. Walker. University of Southern California. [https://sites.google.com/site/wccfl28pro/ alexopoulou-folli]

Aljović, N. 2002. Long adjectival inflection and specificity in Serbo-Croatian. Recherches Linguistiques de Vincennes 31:27-42.

Anagnostopoulou, E. 1994. Clitic dependencies in Modern Greek. University of Salzburg. Ph.D Thesis. 
Anagnostopoulou, E. 1999. Conditions on clitic doubling in Greek. Clitics in the languages of Europe, ed. H. van Riemsdijk, 761-798. Berlin: Mouton de Gruyter.

Anagnostopoulou, E. 2005. Clitic Doubling. The Blackwell Companion to Syntax. Volumes I-V, eds. M. Everaert \& H. van Riemsdijk, Vol. I, 519-580. Oxford: Blackwell.

Anagnostopoulou, E. \& Giannakidou, A. 1995. Clitics and prominence, or why specificity is not enough. CLS 31: Papers from the 31st Annual Meeting of the Chicago Linguistic Society, Volume 2: Parasession on clitics, eds. A. Dainora, R. Hemphill, B. Luka, B. Need \& S. Pragman, 1-15. Chicago: University of Chicago Press.

Androulakis, A. 2001. Clitics and doubling in Greek. Reading Working Papers in Linguistics 5:85-111.

Androulakis, A. 2010. Clitics and gaps. University of Reading. Ph.D Thesis.

Belletti, A. 2004. Aspects of the low IP area. The structure of CP and IP: The cartography of syntactic structures, Vol. 2, ed. L. Rizzi, 16-51. Oxford: Oxford University Press.

Belletti, A. \& Shlonsky, U. 1995. The order of verbal complements: A comparative study. Natural Language and Linguistic Theory 13:489-526.

Bianchi, V. \& Frascarelli, M. 2010. Is topic a root phenomenon?. IBERIA: an International Journal of Theoretical Linguistics 2:43-88.

BürING, D. 1999. Topic. Focus: Linguistic cognitive and computational perspectives, eds. P. Bosch \& R. van der Sand, 142-165. Cambridge: Cambridge University Press.

Bowers, J. 1993. The syntax of predication. Linguistic Inquiry 24:591-656.

Bowers, J. 2001. Predication. The handbook of contemporary syntactic theory, eds. M. Baltin \& C. Collins, 299-333. Oxford: Blackwell.

Chafe, W. 1987. Cognitive constrains on information flow. Coherence and grounding in discourse, ed. R. Tomlin, 21-51. Amsterdam: John Benjamins.

Chomsky, N. 2007. Approaching UG from below. Interfaces + recursion $=$ language? Chomsky's minimalism and the view from syntax-semantics, eds. U. Sauerland \& H.-M. Gärtner, 1-30. Berlin: Mouton de Gruyter.

Сномsкy, N. 2008. On phases. Foundational issues in linguistic theory, eds. R. Freidin, C. Otero \& M. L. Zubizarreta, 133-166. Cambridge, MA: MIT Press.

Cinque, G. 1990. Types of A-bar dependencies. Cambridge, MA: MIT Press.

Сiтко, B. 2008. Small clauses reconsidered: Not so small and not all alike. Lingua 118:261-295.

Сiтко, B. 2011. Small clauses. Language and Linguistics Compass 5:748-763.

Costa, J. 2010. Prosodic prominence: A syntactic matter? The sound pattern of syntax, ed. N. Erteschik-Shir, 93-109. Oxford: Oxford University Press.

Costa, J. \& Figueiredo, M.C. 2006. On the (in)dependence relation between syntax and pragmatics. The architecture of focus, eds. V. Molnär \& S. Winkler, 83-104. Berlin/New York: Mouton de Gruyter.

Culicover, P. W. \& Levine, R. D. 2001. Stylistic inversion and the that- $t$ effect in English: A reconsideration. Natural Language and Linguistic Theory 19:283-310.

Culicover, P. W. \& Winkler, S. 2008. English focus inversion. Journal of Linguistics 44:625-658.

Demonte, V. 1988. Remarks on secondary predicates: c-command, extraction and reanalysis. The Linguistic Review 6:1-39.

Demonte, V. 1995. Dative alternation in Spanish. Probus 7:5-30. 
Demonte, V. \& Masullo, P. 1999. La predicación: Los complementos predicativos. Gramática Descriptiva de la Lengua Española, eds. I. Bosque \& V. Demonte, 2461-2524. Madrid, RAE-Espasa Calpe.

Diesing, M. 1992. Indefinites. Cambridge, MA: MIT Press.

Diesing, M. 1997. Yiddish VP order and the typology of object movement in Germanic. Natural Language and Linguistic Theory 15:369-427.

Den Dikken, M. 2006. Relators and linkers: The syntax of predication, predicate inversion, and copulas. Cambridge, MA: MIT Press.

ENÇ, M. 1991. The semantics of specificity. Linguistic Inquiry 22:1-25.

ERTESCHIK-Shir, N. 1997. The dynamics of focus structure. Cambridge: Cambridge University Press.

Erteschik-Shir, N. 2006. On the architecture of topic and focus. The Architecture of Focus, eds. V. Molnár \& S. Winkler, 33-58. Berlin: Mouton de Gruyter.

Francom, J. 2003. La cláusula reducida y el orden libre de palabras en español. Divergencias: Revista de Estudios Lingüísticos y Literarios 1:29-43.

Frascarelli, M. 2007. Subjects, topics and the interpretation of referential pro: an interface approach to the linking of (null) pronouns. Natural Language and Linguistics 25:691-734.

Frascarelli, M. \& Hinterhölzl, R. 2007. Types of topics in German and Italian. On information structure, meaning and form, eds. K. Schwabe \& S. Winkler, 87-116. Amsterdam: John Benjamins.

Georgiafentis, M. \& Sfakianaki, A. 2004. Syntax interacts with prosody: The VOS order in Greek. Lingua 114:935-961.

Gill, K.-H. \& Tsoulas, G. 2004. Peripheral effects without peripheral syntax: The left periphery in Korean. Peripheries, eds. D. Adger, C. de Cat \& G. Tsoulas, 121-142. Kluwer: Dordrecht.

Givón, T. 1983. Topic continuity in discourse: An introduction. Topic continuity in Discourse: A quantitative crosslanguage study, ed. T. Givón, 5-41. Amsterdam: John Benjamins.

Groos, A. \& BoK-Bennema, R. 1985. The structure of the sentence in Spanish. Generative Studies in Spanish Syntax, eds. I. Bordelois, H. Contreras \& K. Zagona, 67-80. Dordrecht: Foris.

GuÉmanN, S.A. 1990. Secondary predicates in English and Spanish. University of California at Berkeley. Ph.D Thesis.

Haegeman, L. 2010. The internal syntax of adverbial clauses. Lingua 120:628648.

Hong, S. \& Lasnik, H. 2010. A note on 'Raising to Object' in small clauses and full clauses. Journal of East Asian Linguistics 19:275-289.

İsseVER, S. 2003. Information structure in Turkish: The word order-prosody interface. Lingua 113:1025-1053.

Jayaseelan, K. A. 2001. IP-internal topic and focus phrases. Studia Linguistica 55:39-75.

JiMÉNEZ-FernÁNDEZ, Á. L. 2000. The aspectual morpheme as and feature movement in argument small clauses. Generative Linguistics in Poland 1:59-69.

JimÉNEZ-FERnÁNDEZ, Á. L. 2002. El aspecto léxico y las partículas aspectuales en las cláusulas reducidas argumentales. Léxico y gramática, ed. G. Veiga, 203-214. Lugo: Tris Tram.

JimÉneZ-FernánDEZ, Á. L. 2010. Discourse-agreement features, phasal C and the edge: A minimalist approach. Diacrítica - Language Sciences Series 24:25-48.

JimÉnEZ-FERnÁnDEZ, Á. L. 2011. On the order of multiple topics and discoursefeature inheritance. Dilbilim Araştırmaları (Journal of Linguistic Research) 2011:5-32. 
JiMÉNEZ-FERNÁNDEZ, Á. L. 2012. What information structure tells us about individual/stage-level predicates. Borealis (An International Journal of Hispanic Linguistics) 1:1-32.

Jiménez-Fernández, Á. L. Forthcoming. Phasal heads, discourse/agreement features, and word order. Issues in Mediterranean syntax, eds. A. S. Özsoy \& A. Gürel.

Kazazis, K. \& Pentheroudakis, J. 1976. Reduplication of indefinite direct objects in Albanian and Modern Greek. Language 52:398-403.

KeEnAn, E. \& Stavi, J. 1986. A semantic characterization of natural language determiners. Linguistics and Philosophy 9:253-326.

Kenesei, I. 2006. Focus as identification. The architecture of focus, eds. V. Molnár \& S. Winkler, 137-168. Berlin: Mouton de Gruyter.

KIss, K. É. 1998. Identificational focus versus information focus. Language 74:245-273.

Kiss, K. É. 2002. The syntax of Hungarian. Cambridge: Cambridge University Press.

Kitagawa, Y. 1985. Small but clausal. Chicago Linguistic Society 21:210-220.

KornfiLt, J. 2003. Scrambling, subscrambling, and case in Turkish. Word order and scrambling, ed. S. Karimi, 125-155. Oxford: Blackwell.

Kratzer, A. 1995. Stage-level and individual-level predicates. The generic book, eds. G. Carlson \& F. J. Pelletier, 125-175. Chicago, University of Chicago Press.

KunO, S. 1976. Subject, theme, and the speaker's empathy: A reexamination of relativization phenomena. Subject and topic, ed. C. Li, 417-444. New York: Academic Press.

Lasnik, H. \& SAito, M. 1992. Move $\alpha$ : Conditions on its application and output. Cambridge, MA: MIT Press.

LASNIK, H. 1999. Minimalist analysis. Oxford: Blackwell.

LACA, B. 1987. Sobre el uso del acusativo preposicional en español. El complemento directo preposicional, ed. C. Pensado, 61-91. Madrid: Visor.

LAmbrecht, K. 1994. Information structure and sentence form: Topic, focus and the mental representations of discourse referents. Cambridge:Cambridge University Press.

Leech, G. \& J. Svartvik. 2002. A communicative grammar of English. Harlow: Pearson Education Limited.

LeONETTI, M. 2004. Specificity and differential object marking in Spanish. Catalan Journal of Linguistics 3:75-114.

LeOnetTi, M. 2008. Definiteness effects and the role of the coda in existential constructions. Essays on nominal determination: From morphology to discourse management, eds. H. Høeg Müller \& A. Klinge, 131-162. Amsterdam:John Benjamins.

LóPEz, L. 2009. A derivational syntax for information structure. Oxford:Oxford University Press.

Lyons, C. 1999. Definiteness. Cambridge: Cambridge University Press.

MALLÉN, E. 1991. A syntactic analysis of secondary predication in Spanish. Journal of Linguistics 27:375-403.

Miyagawa, S. 2005. On the EPP. Perspectives on phases, eds. N. Richards \& M. McGinnis, 201-236. Cambridge, MA: MIT Press.

Miyagawa, S. 2010. Why agree? Why move? Unifying agreement-based and discourse-configurational languages. Cambridge, MA: MIT Press.

Molnár, V. 2006. On different kinds of contrast. The architecture of focus, eds. V. Molnár \& S. Winkler, 197-234. Berlin: Mouton de Gruyter. 
Moreno, N. \& Pérez, I. 2004. Information structure and the referential status of bare plurals. University of Connecticut Working Papers in Linguistics 12:39-43.

Neeleman, A. \& van de Koot, H. 2008. Dutch scrambling and the nature of discourse templates. The Journal of Comparative Germanic Linguistics 11: 137-189.

Ordoñez, F. 1998. Post-verbal asymmetries in Spanish. Natural Language \& Linguistic Theory 16:313-346.

Pesetsky, D. 1987. Wh-in-situ: Movement and unselective binding. The representation of (in) definiteness, eds. E. Reuland \& A. ter Meulen, 98-129. Cambridge, MA: MIT Press.

Platzack, C. 1986. Inverterad objekt med infinitiv. Nysvenska Studier 66:89-111.

Postal, P. 1974. On raising. Cambridge, MA: MIT Press.

PhilippaKi-Warburton, I. 1985. Word order in Modern Greek. Transactions of the Philological Society 83:113-143.

Philippaki-Warburton, I. 1987. The theory of empty categories and the pro-drop parameter in Modern Greek. Journal of Linguistics 23:289-318.

Raposo, E. \& Uriagereka, J. 1995. Two types of small clauses (Toward a syntax of theme/rheme relations). Syntax and semantics: Small clauses, eds. A. Cardinaletti \& M.T. Guasti, 179-206. New York, Academic Press.

Reinhart, T. 1981. Pragmatics and linguistics: An analysis of sentence topics. Philosophica 27:53-94.

Revithiadou, A. 2005. Prosodic phrasing and focus in Greek declaratives. Proceedings of the 6th International Conference of Greek Linguistics, eds. G. Catsimali, E. Anagnostopoulou, A. Kalokerinos \& I. Kappa, Vol. I, 64-74. Rhethymnon: University of Crete.

RichARDS, M. On feature-inheritance: an argument from the Phase Impenetrability Condition. Linguistic Inquiry 38:563-572.

RizzI, L. 1997. The fine structure of the left periphery. Elements of grammar: Handbook of generative syntax, ed. L. Haegeman, 281-337. Dordrecht: Kluwer.

RizzI, L. 2004. Locality and left periphery. Structures and beyond: The cartography of syntactic structures Vol. 3, ed. A. Belletti, 223-251. New York: Oxford University Press.

Ross, J. 1967. Constraints on variables in syntax. MIT. Ph.D Thesis.

Rothstein, S. D. 1983. The syntactic forms of predication. MIT. Ph.D Thesis.

Spyropoulos, V. 1998. The structure of small clauses in Modern Greek. Themes in Greek linguistics II, eds. B. Joseph, G. Horrocks \& I. Philippaki-Warburton, 169-196. Amsterdam: John Benjamins.

Spyropoulos, V. 1999. Agreement relations in Greek. University of Reading. Ph.D Thesis.

Starke, M. 1995. On the format for small clauses. Syntax and semantics: Small clauses, eds. A. Cardinaletti \& M. T. Guasti, 237-269. New York, Academic Press.

Stowell, T. 1981. Origins of phrase structure. MIT. Ph.D Thesis.

Stowell, T. 1991. Small Clause restructuring. Principles and Parameters in Comparative Grammar, ed. R. Freidin, 182-218. Cambridge, MA: MIT Press. STRAwSON, P. 1964. Identifying reference and truth values. Theoria 30:96-118.

SuÑER, M. 2003. The lexical preverbal subject in a Romance null subject language: Where art thou? A Romance perspective in language knowledge and use, eds. R. Núñez-Cedeño, L. López \& R. Cameron, 341-357. Amsterdam: John Benjamins.

Tsokoglou, A. 1997. Small Clauses in Modern Greek. Greek Linguistics '95: Proceedings of the 2nd International Conference on Greek Linguistics Vol. II, ed. 


\section{0 Ángel L. Jiménez-Fernández \& Vassilios Spyropoulos}

G. Drachman, A. Malikouti-Drachman, J. Fykias \& C. Klidi, 641-650. Graz: Neubauer Verlag.

Valmala, V. 2008. Topic, focus and quantifier float. Gramatika jaietan: Patxi Goenagaren omenez, eds. X. Artiagoitia Beaskoetxea \& J.A. Lakarra Andrinua. Vitoria: UPV.

Williams, E. S. 1980. Predication Linguistic Inquiry 11:203-238.

Williams, E. S. 1983. Against small clauses. Linguistic Inquiry 14:287-308.

Zubizarreta, M. L. 1998. Prosody, focus, and word order. Cambridge, MA: MIT Press.

Zubizarreta, M. L. 2010. The syntax and prosody of focus: The Bantu-Italian connection. Iberia: An International Journal of Theoretical Linguistics 2:131168.

Received January 10, 2012

Ángel L. Jiménez-Fernández Accepted August 14, 2012

Departamento de Lengua Inglesa

Facultad de Filología

Universidad de Sevilla

C/ Palos de la Frontera s/n

41004 Sevilla

Spain

ajimfer@us.es

Vassilios Spyropoulos

Department of Linguistics

Faculty of Philology

School of Philosophy

University of Athens

University Campus at Zographou

Athens 15784

Greece

vspyrop@phil.uoa.gr 


\section{Please correct and return this set}

Please use the proof correction marks shown below for all alterations and corrections. If you wish to return your proof by fax you should ensure that all amendments are written clearly in dark ink and are made well within the page margins.

\begin{tabular}{|c|c|c|}
\hline Instruction to printer & Textual mark & Marginal mark \\
\hline Leave unchanged & ... under matter to remain & ( \\
\hline $\begin{array}{l}\text { Insert in text the matter } \\
\text { indicated in the margin }\end{array}$ & $h$ & $\begin{array}{l}\text { New matter followed by } \\
h \text { or } h \otimes\end{array}$ \\
\hline Delete & $\begin{array}{l}\text { I through single character, rule or underline } \\
\text { or }\end{array}$ & $\sigma$ or $\sigma / \otimes$ \\
\hline $\begin{array}{l}\text { Substitute character or } \\
\text { substitute part of one or } \\
\text { more word(s) }\end{array}$ & / through letter or & $\begin{array}{l}\text { new character / or } \\
\text { new characters / }\end{array}$ \\
\hline Change to italics & — under matter to be changed & $\leftarrow$ \\
\hline Change to capitals & $\equiv$ under matter to be changed & $\equiv$ \\
\hline Change to small capitals & $=$ under matter to be changed & $=$ \\
\hline Change to bold type & $\sim$ under matter to be changed & $\sim$ \\
\hline Change to bold italic & $\approx$ under matter to be changed & $\underline{s i n}$ \\
\hline Change to lower case & Encircle matter to be changed & $\not$ \\
\hline Change italic to upright type & (As above) & \\
\hline Change bold to non-bold type & (As above) & \\
\hline Insert 'superior' character & $\begin{array}{l}\text { I through character or } \\
K \text { where required }\end{array}$ & $\begin{array}{l}y^{\prime} \text { or } y \\
\text { under character } \\
\text { e.g. } y^{2} \text { or } y^{2}\end{array}$ \\
\hline Insert 'inferior' character & (As above) & $\begin{array}{l}\text { L } \\
\text { over character } \\
\text { e.g. } \hat{\imath}\end{array}$ \\
\hline Insert full stop & (As above) & $\odot$ \\
\hline Insert comma & (As above) & , \\
\hline Insert single quotation marks & (As above) & $\begin{array}{l}\dot{y} \text { or } \dot{X} \text { and/or } \\
\dot{y} \text { or } \dot{X}\end{array}$ \\
\hline Insert double quotation marks & (As above) & $\begin{array}{l}\ddot{y} \text { or } \ddot{y} \text { and/or } \\
\ddot{y} \text { or } \ddot{x}\end{array}$ \\
\hline Insert hyphen & (As above) & $1-1$ \\
\hline Start new paragraph & $\digamma$ & 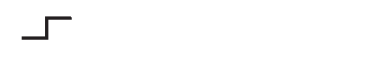 \\
\hline No new paragraph & $\infty$ & $\omega$ \\
\hline Transpose & $\sqcup$ & ᄃ \\
\hline Close up & linking $\bigcirc$ characters & \\
\hline $\begin{array}{l}\text { Insert or substitute space } \\
\text { between characters or words }\end{array}$ & $\begin{array}{l}\text { I through character or } \\
\Lambda \text { where required }\end{array}$ & \\
\hline $\begin{array}{l}\text { Reduce space between } \\
\text { characters or words }\end{array}$ & $\begin{array}{l}\text { between characters or } \\
\text { words affected }\end{array}$ & $\uparrow$ \\
\hline
\end{tabular}

